\title{
The Pennsylvanian Joggins Formation of Nova Scotia: sedimentological log and stratigraphic framework of the historic fossil cliffs
}

\author{
S.J. Davies ${ }^{1^{*}}$, M.R. Gibling ${ }^{2}$, M.C. RygeL ${ }^{2 \dagger}$, J.H. Calder ${ }^{3}$, And D.M. Skilliter ${ }^{4}$ \\ 1. Department of Geology, University of Leicester, Leicester LE1 7RH, U.K. <sjd27@leicester.ac.uk> \\ 2. Department of Earth Sciences, Dalhousie University, Halifax, Nova Scotia B3H 3J5 Canada \\ 3. Nova Scotia Department of Natural Resources, P.O. Box 698, Halifax, Nova Scotia B3J 2T9 Canada \\ 4. Nova Scotia Museum, 1747 Summer St., Halifax, Nova Scotia B3H 3A6 Canada \\ *corresponding author \\ $\dagger$ Present address: Department of Geoscience, 214 Bessy Hall, \\ University of Nebraska-Lincoln, Lincoln, Nebraska, 68588, USA
}

Date received:14 January 2005 g Date accepted 9 August 2005

\begin{abstract}
Carboniferous strata of the famous Joggins fossil cliffs hold a unique place in the history of geology. Made famous by the fossil discoveries of Lyell and Dawson in the mid 1800s, the cliffs continue to yield important information about paleobiology. The Joggins Formation (of probable Langsettian age) has been completely remeasured for the first time since Logan and Dawson's pioneering studies, and a visual log and a map of the foreshore illustrate the $915.5 \mathrm{~m}$ of strata along Chignecto Bay. Formation boundaries are formally described, and two informal members are abandoned. The formation is divided into 14 cycles, most of which commence with major transgressions represented by the openwater facies assemblage, some faunal elements of which show a restricted-marine affinity. Higher in the cycles, the re-advance of coastal and alluvial systems yielded poorly and well drained facies assemblages, respectively. The main levels of standing trees, dominated by lycopsids, were entombed where distributary channels brought sand into coastal wetlands. Some trees contain tetrapods and invertebrates, which may have sought refuge or become trapped in hollow trees. Cordaitalean (gymnosperm) forests covered the alluvial plains and basin-margin uplands, and were periodically swept by wildfires. The predominance of flooding surfaces and the apparent absence of lowstand exposure surfaces reflect the rapid subsidence of the Cumberland Basin controlled by active basin-margin faults and salt withdrawal. The cycles may reflect tectonic events, glacioeustatic sea-level fluctuations, and/or variations in sediment flux.
\end{abstract}

\section{RÉSUMÉ}

Les strates carbonifères des célèbres falaises fossilifères de Joggins occupent une place unique au sein de l'histoire de la géologie. Devenues célèbres à la suite des découvertes de fossiles de Lyell et Dawson vers le milieu du $19^{\mathrm{e}}$ siècle, les falaises continuent à fournir des données précieuses au sujet de la paléobiologie. La Formation de Joggins (qui remonte vraisemblablement au Langsettien) a été entièrement remesurée pour la première fois depuis les premières études importantes du secteur réalisées par Logan et Dawson; une description visuelle et une carte de l'estran illustrent les 915,5 mètres de strates le long de la baie Chignectou. L'étude décrit officiellement les limites de la formation et abandonne deux membres officieux. La formation est subdivisée en 14 cycles dont la majorité commencent avec des transgressions importantes représentées par l'assemblage de faciès en eaux libres, dont certains éléments fauniques présentent une affinité marine restreinte. À des niveaux supérieurs des cycles, la récurrence des systèmes côtiers et alluviaux fournit des assemblages de faciès mal drainés et bien drainés, respectivement. Les principaux niveaux d'arbres sur pieds, à prédominance de lycopsides, ont été enfouis dans des secteurs où des canaux tertiaires ont apporté du sable à l'intérieur des terres humides côtières. Certains arbres renferment des tétrapodes et des invertébrés, lesquels pourraient avoir cherché refuge ou s'être retrouvés prisonniers dans des arbres creux. Des forêts cordaitaléennes (gymnospermes) ont couvert les plaines alluviales et les terres hautes de marge de bassin, et ont périodiquement été balayées par des incendies de forêt. La prédominance de surfaces d'inondation et l'absence apparente de surfaces d'affleurement de bas niveau témoignent de la subsidence rapide du bassin de Cumberland, contrôlée par des failles de marge de bassin actives et un retrait du sel. Les cycles pourraient correspondre à des événements tectoniques, à des fluctuations glacio-eustatiques du niveau de la mer ou à des variations du débit de sédiments. 
[Traduit par la rédaction]

\section{THE JOGGINS CLIFFS}

The Joggins fossil cliffs constitute one of the world's most remarkable and historic stratigraphic sections. The cliffs extend from Lower Cove past Joggins village to McCarron's Creek, bordering a broad tidal platform along Chignecto Bay, where some of the world's highest tides continually erode Carboniferous strata of the Cumberland Basin (Figs. 1, 2). The Joggins Formation comprises only $2.8 \mathrm{~km}$ of a $30 \mathrm{~km}$ long continuous coastal section that Sir Charles Lyell (1871, p. 410) described as "the finest example in the world of a natural [Carboniferous coal measures] exposure", a view that is still widely accepted.

Early accounts by Jackson and Alger (1828), Brown and Smith (1829), and Gesner (1836) brought the Joggins section to the attention of the world. Lyell visited Joggins during his first visit to North America and was deeply impressed by the spectacular geological features (Lyell 1845; Scott 1998). In the following year, Joggins hosted William Logan, the head of the newly constituted Geological Survey of Canada, who recorded a 14570 foot $(4441 \mathrm{~m})$, virtually continuous section along Chignecto Bay (Logan 1845; Rygel and Shipley 2005).

For the remainder of the century, Lyell, J.W. Dawson and other Victorian luminaries repeatedly visited the cliffs, a particular highlight being the discovery in 1852 of tetrapod bones and land snails within tree trunks (Lyell and Dawson 1853; Dawson 1878, 1882). In many ways, Joggins was to Lyell what the Galapagos Islands were to Darwin (Calder 2003). Lyell's research at Joggins, following the earlier success of "Principles of Geology" (Lyell 1830-1833), was pivotal in establishing the stratigraphic record as an archive of Earth's evolving landscape. Joggins is mentioned several times in Charles Darwin's “Origin of Species" (1859). The cliffs have yielded some of the world's best preserved fossil forests, the earliest known true reptile (Hylonomuslyelli), and the first land snail(Dendropupa vetusta - referred to as "miserable little dendropupa" by Bishop Sam Wilberforce during the famous British debate on evolution in the 1860s (Wilberforce 1860, p. 244).

Over the past 25 years, the natural laboratory of the Joggins cliffs - renewed constantly by the tides - has experienced a surge of scientific interest. Paleontological research has touched upon the main forested levels and the entombment of standing trees and their contained fossils (Rygel et al. 2004; Calder et $a l$. in press), wetland and dryland plant assemblages (FalconLang and Scott 2000; Falcon-Lang 2003a,b), charcoal and the wildfire record (Falcon-Lang 1999), and age assessment (Dolby 1991; Utting and Wagner 2005). There have been discoveries of reptiles, bivalves, ostracodes, gastropods and foraminifera, as well as tetrapod trackways and other trace fossils (Solem and Yochelson 1979; Archer et al. 1995; Reisz 1997; Hebert and Calder 2004; Falcon-Lang et al. 2004a; Tibert and Dewey 2005). Sedimentological research has investigated channel bodies (Rygel et al. 2001; Rygel 2005), paleosols (Smith 1991), sequence stratigraphy (Davies and Gibling 2003), and composition of coals and carbonaceous strata (Gibling and Kalkreuth 1991; Hower et al. 2000). Scott (2001) and Falcon-Lang et al. (2004b) presented general scientific accounts. In 2004, Joggins was proposed for Canada's list of World Heritage nominations (Falcon-Lang and Calder 2004).

Despite the importance of the Joggins cliffs, the only formal stratigraphic log has remained the detailed written descriptions of Logan (1845) and Dawson (1854). Later workers have remeasured short segments, and Ryan and Boehner (1994) recast Logan's log as a simplified graphic log. We have remeasured the cliff and foreshore section ( $915.5 \mathrm{~m}$ thick) from Lower Cove to south of Bell's Brook, the lower $600 \mathrm{~m}$ of which was described by Davies and Gibling (2003), and an interval of $145 \mathrm{~m}$ higher in the section by Tenière (1998). In Appendix A we present a complete sedimentological log, with a notation of Logan's numbered coals and Dawson's Coal Divisions, and present a map of the foreshore that shows the stratigraphic height in metres above the base of the Joggins Formation, so that historic and future fossil discoveries may be accurately positioned. We also present formal revision to the upper boundary of the Joggins Formation, and review the formation's cyclicity and depositional setting. A companion paper (Calder et al. 2005) presents the section at Lower Cove and formally designates the latter strata as the Little River Formation, and in so doing redefines the Joggins Formation. We hope that these publications will encourage further research on this superb and historic section.

\section{STRATIGRAPHIC FRAMEWORK FOR THE JOGGINS FORMATION}

\section{Previous research}

Ryan et al. (1991), Ryan and Boehner (1994) and Calder (1998) summarized the history of stratigraphic nomenclature for the Cumberland Basin, and Calder et al. (2005) set out more fully the history of stratigraphic work in the Joggins area. Previous approaches to subdividing the Joggins stratal interval are outlined in Figs. 3 and 4. Despite its magnificence, the coastal exposure provides only a two-dimensional view of the basinal strata, and a full regional understanding is complicated by minimal exposure inland, the presence of Chignecto Bay, and complex facies relationships southward towards the Cobequid Highlands (Fig. 1), which was an active, fault-bounded upland during deposition of the Joggins Formation. In proposing a stratigraphic framework, every researcher since Logan has wrestled with this difficult background.

Logan (1845) divided the Chignecto Bay strata into eight divisions (numbered from the top downwards), placing the predominantly grey, coal-bearing strata of the Joggins cliffs in Division 4. He measured this interval as $2539^{\prime} 1 "$ " (774 m) of grey and red mudstone, sandstone, limestone, coal, carbonaceous shale and minor conglomerate. Logan recognized 45 coal groups (identified with numbers) in Division 4, and recorded an aggregate thickness of 37' 9.5" (11.5 m) of coal and 23' 3" (7.1 


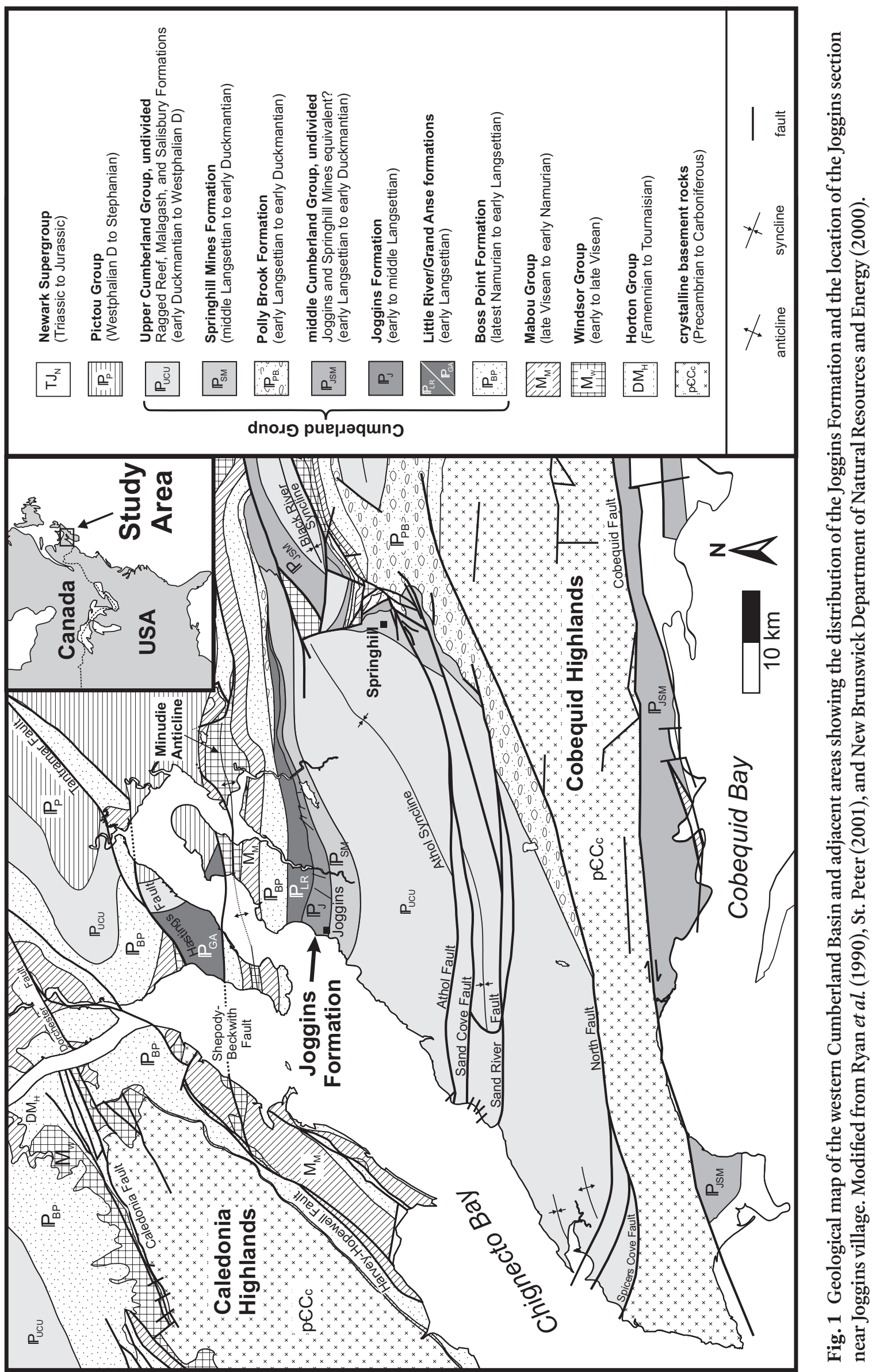


Fig. 2 Stratigraphic position of the Joggins Formation within the Cumberland Group. Modified from Ryan et al. (1990) and St. Peter (2001).

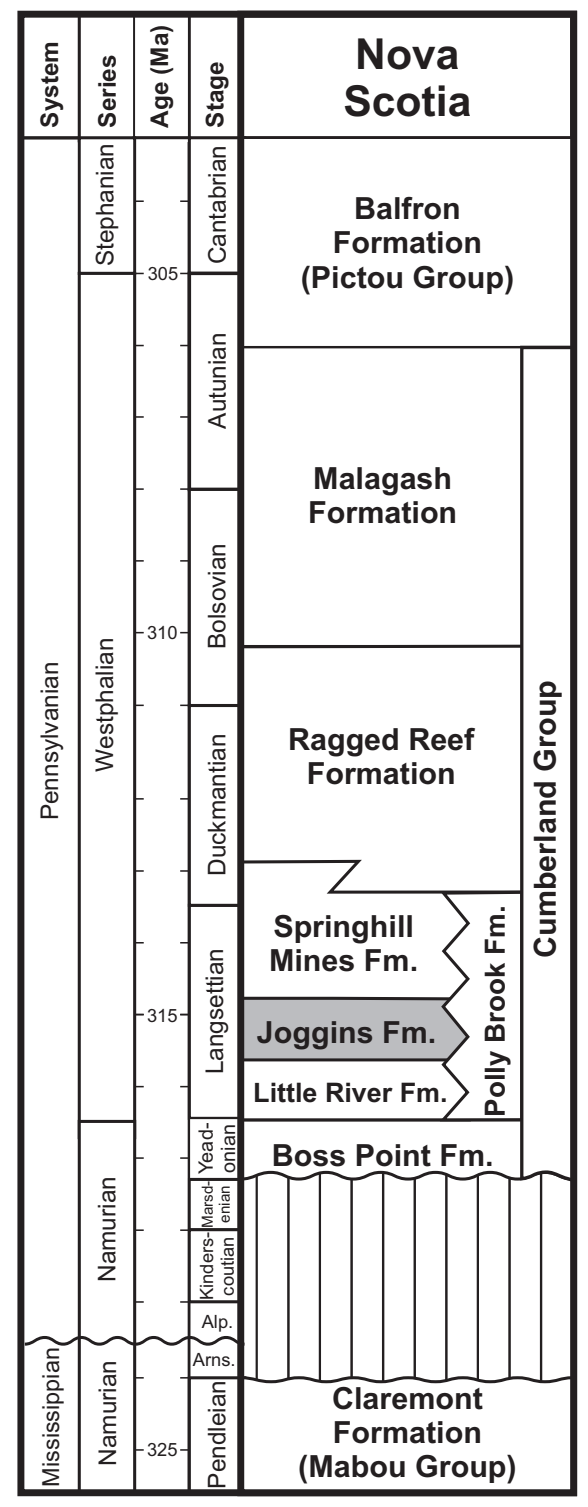

$\mathrm{m})$ of limestone in the division. Red, red-green and chocolate shale and sandstone constituted $264 \mathrm{~m}$ (34\%) of his section, the remainder being grey. In contrast, he noted the absence of coal in the underlying Division 5, which he described as red mudstone and grey and red sandstone, with a few green shale and calcareous nodular horizons. This division, only partially exposed at Lower Cove, was measured at 2082' $(635 \mathrm{~m})$ down to the top of "South Reef", a prominent and thick sandstone body within Division 6. Logan's Coal Group 45 lies slightly above the base of Division 4 at Lower Cove, and was described as comprising 10' 2 " (3.1 m) of coal, carbonaceous shale and interbedded shale and sandstone, with a basal thin coal 3" $(7.5 \mathrm{~cm})$ thick. These strata are underlain by $5^{\prime} 6^{\prime \prime}(1.7 \mathrm{~m})$ of underclay and red shale and sandstone, the base of which marks the base of Division 4. The top of Coal Group 1 marks the top of Division 4 near Joggins village, where a 4' $(1.2 \mathrm{~m})$ limestone rests upon a $1^{\prime}(0.3 \mathrm{~m})$ coal. The overlying Division 3 has a lesser proportion of coal (22 seams with only $5^{\prime} 5^{\prime \prime}$ or $1.7 \mathrm{~m}$ aggregate thickness), a greater proportion of red beds and, most significantly, no limestone. Division 2 is mainly red sandstone and mudstone.

Subsequent workers used aspects of Logan's classification. Dawson $(1854,1855)$ divided Division 4 into 27 coal divisions (designated with Roman numerals), and provided more detail for some of Logan's coal groups. Dawson(1868) adopted aspects of British terminology in identifying a Millstone Grit Series and a Middle Coal Formation, a system that was modified by Bell (1912). Bell (1914) subsequently proposed the name "Joggins Formation" for Divisions 5, 4, 3 and part of 2, an interval 6886' (2099 m) thick, and the name "Shulie Formation" for overlying strata (most of Division 2 and Division 1). Bell discussed the rationale for combining the Division 5 red beds and the Division 4 grey, coal-bearing beds into one formation, inferring that a regional disconformity underlies Division 5 within the Cumberland Basin (although it is not apparent in the coastal

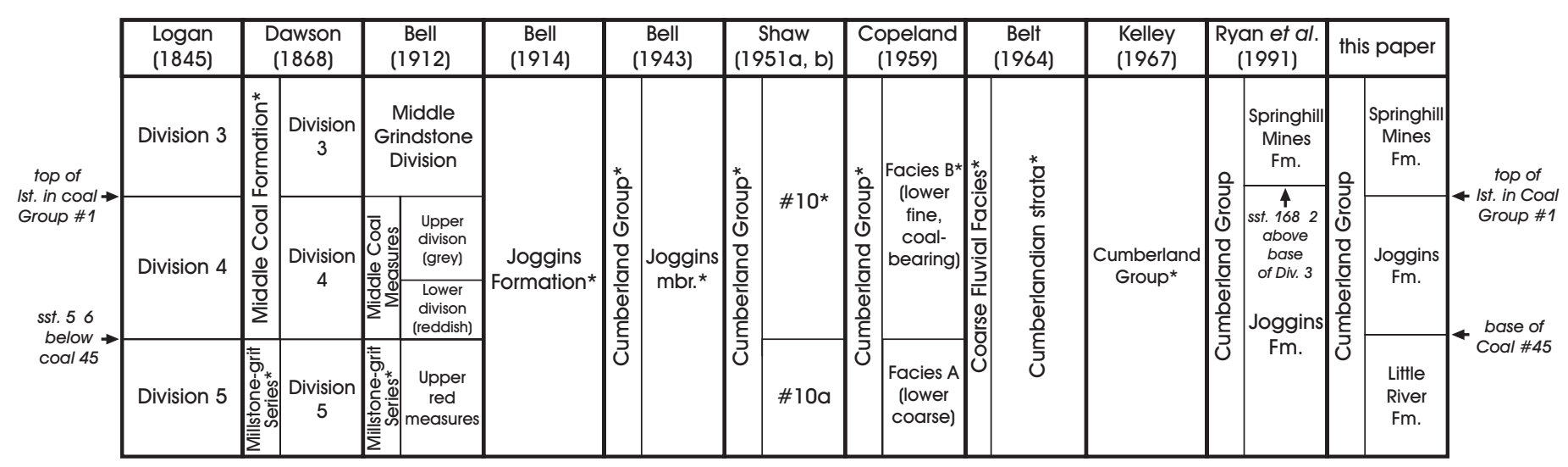

Fig. 3 Comparative stratigraphic chart showing the evolution of nomenclature for the Joggins Formation and associated strata in the Cumberland Basin. Vertical axis is approximately scaled to the thickness of the units. Chart refers only to major stratigraphic revisions that affected subdivision of the coastal section. Asterisks denote units that are partially shown. Modified from Ryan et al. (1991). 
section). He subsequently retracted the formation names (Bell 1943) due to problems in correlating units inland, arising in part from miscorrelation of the coal-bearing strata of Spicers Cove with those of Division 4 to the north at Joggins. Bell combined the Joggins and Shulie formations as the "Joggins member" of an undivided Cumberland Group. Shaw (1951a,b) mapped coarser and finer rock units within the basin, and assigned the Joggins grey strata to his unit 10, noting that conglomeratic wedges near the Cobequid Highlands thin northward and complicate the basinal stratigraphy. Copeland (1959) followed this approach, and confirmed that coals thin inland within the Joggins-Chignecto coalfield. Belt (1964) referred strata at this level across the region to the "Coarse Clastic Facies", but Kelley (1967) retained the Cumberland Group for the lower part of this interval.

Ryan et al. (1991) reinstated the Joggins Formation and presented a formal description with the Joggins cliffs as the type section. Ryan et al. (1990) mapped the formation inland, and included Divisions 5, 4 and the basal strata of Division 3 within the reconstituted Joggins Formation, for a total thickness of $1433 \mathrm{~m}$. Both Ryan et al. (1991) and Ryan and Boehner (1994) illustrated member boundaries on a column derived from Logan's section (their figs. 5 and 2-13, respectively), but did not elaborate on them in the text. The figures show three informal members: the Little River Bridge member (Division 5), the Coal Mine Point member, and the Bells Brook member (Division 4 and basal strata of Division 3), but these members were not formally defined or shown on the accompanying maps.
In the coastal section, Logan's Division $5 / 6$ boundary was taken to mark the base of the Joggins Formation, and its top was placed at the base of a thick sandstone body that ushers in a more sand-dominated interval at the base of their new Springhill Mines Formation (Ryan et al. 1991; Ryan and Boehner 1994). This upper boundary was selected by Ryan et al. (1991) who placed the basal 168' 2" (51 m) of Division 3 within the Joggins Formation. This contact has proven difficult to map.

\section{Modifications to Joggins Formation definition at the type section}

Remeasurement of the section (Appendix A of this paper, and Appendix A of Calder et al. 2005) has led Calder et al. (2005, their Appendix C) to redefine the Joggins Formation from the boundaries set out by Ryan et al. (1991) (Fig. 4). Below, we describe the boundaries of the revised formation at the coastal type section as they relate to our recent sedimentological investigations.

\section{Formation base and top at the type section}

In the absence of a detailed measured section, Ryan $e t$ al. (1991) included Division 5 within the Joggins Formation based on unconfirmed reports of coals within the red beds. With the advantage of a detailed measured section, Calder et al. (2005) reaffirm Logan's observation that Division 5 lacks coal, fossiliferous limestone and grey mudstone. They formally redefine

\begin{tabular}{|c|c|c|}
\hline Logan (1845) & Ryan et al. (1991) & this volume \\
\hline \multirow{2}{*}{$\begin{array}{l}\text { DIVISION } 3 \\
2134(650 \text { m) thick; } \\
\text { mainly red with minor grey; } \\
\text { sst, mdst, and minor } \\
\text { coal/carb. Shale }\end{array}$} & $\begin{array}{l}\text { SPRINGHILL MINES } \\
\text { FORMATION }\end{array}$ & \multirow{2}{*}{$\begin{array}{l}\text { SPRINGHILL } \\
\text { MINES } \\
\text { FORMATION }\end{array}$} \\
\hline & \multirow{2}{*}{ 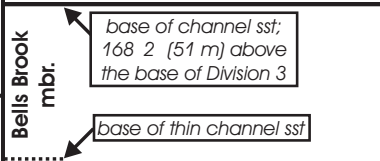 } & \\
\hline $\begin{array}{l}\text { top of } 4 \text { limestone } \\
\text { coppoing coal Group } 1\end{array}$ & & $\begin{array}{l}\text { top of } 4 \text { limestone } \\
\text { copping coal Group } 1\end{array}$ \\
\hline $\begin{array}{c}\text { DIVISION } 4 \\
2539 \text { 1 }(774 \text { m) thick; mainly } \\
\text { grey and coal-bearing; mdst and } \\
\text { sst, coal, carb. shale, limestone } \\
5 \text { base of } 6 \text { sandstone; } \\
56 \text { below coal Group } 45\end{array}$ & 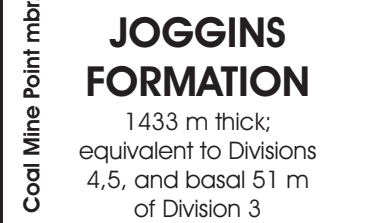 & $\begin{array}{c}\text { JOGGINS } \\
\text { FORMATION } \\
915.5 \mathrm{~m} \text { thick; } \\
\text { roughly equivalent to Division } 4 \\
\text { base of Coal Group } 45\end{array}$ \\
\hline $\begin{array}{l}\text { DIVISION } 5 \\
2082(635 \text { m) thick; } \\
\text { predominantly red; } \\
\text { red sst and mdst, scattered } \\
\text { nodular, calcareous layers }\end{array}$ & 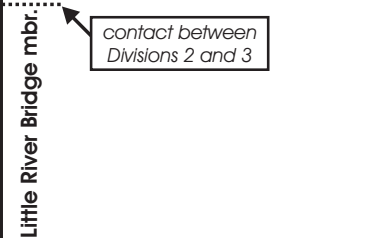 & $\begin{array}{l}\text { LITTLE RIVER } \\
\text { FORMATION } \\
638,5 \mathrm{~m} \text { thick } \\
\text { roughly equivalent to Division } 5\end{array}$ \\
\hline
\end{tabular}

Fig. 4 Definition of Joggins Formation boundaries in the coastal section along Chignecto Bay, as outlined in some key papers. Where strata were originally measured in feet, metric equivalent is shown to nearest metre. $s s t=$ sandstone, mdst $=$ mudstone, carb. $=$ carbonaceous. 


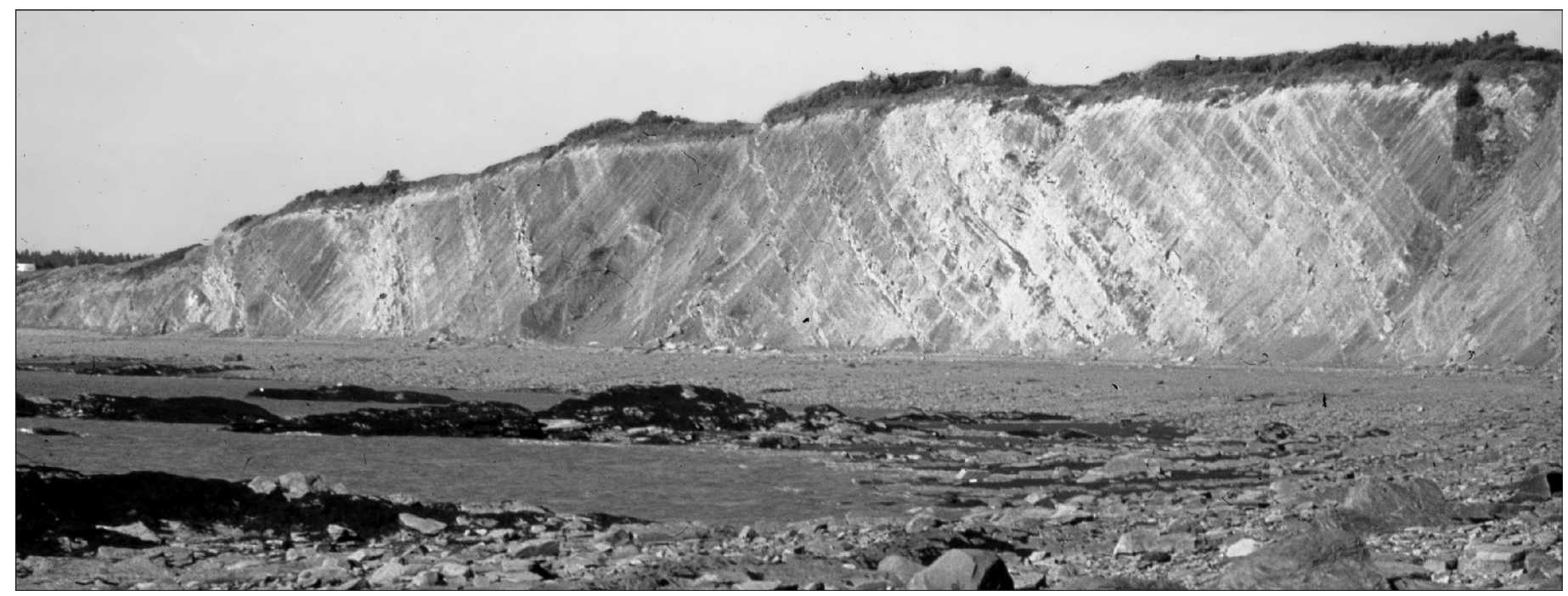

Fig. 5 Basal $250 \mathrm{~m}$ of the Joggins Formation south of Lower Cove (cycles 1-4 and basal strata of cycle 5). Formation base is at extreme left. Cliffs are about $20 \mathrm{~m}$ high, and dark, seaweed-covered reefs in foreground are lenticular channel sandstones.

Division 5 as the Little River Formation (635.8 m thick) and, in so doing, also redefine the Joggins Formation. The base of the Joggins Formation as reformulated by Calder et al. (2005) coincides with the lowermost coal exposed in the section, within Coal Group 45 and $1.7 \mathrm{~m}$ above the base of Division 4 as originally defined by Logan (1845). This approach essentially retains Logan's Division 5 as a unit distinct from both the underlying Boss Point Formation and the overlying Joggins Formation and, in consequence clarifies the definition of the Joggins Formation as a coal-bearing unit with co-occurring bivalve-bearing limestones.

The formation top is redesignated at the top of the uppermost limestone unit within coal group 1 south of Bells Brook in keeping with the original definition of Division 4 by Logan (1845), as opposed to the channel-sandstone base at the higher level designated by Ryan et al. (1991). This limestone/coal interval is unusually thick, and the limestone is the topmost major calcareous unit in the type (cliff) section. Mining records and mapping (Goudge 1945; Shaw 1951b; Copeland 1959; Ryan et al. 1990) show that limestone beds within the interval of mined coal seams of the Joggins Formation (Coals 7-32) extend up to $40 \mathrm{~km}$ inland and can be interpreted as basin-wide flooding events (Calder 1994). Falcon-Lang (2003a) noted that these limestones and overlying platy shales yield abundant remains of upland floral elements, confirming that major flooding events inundated most of the basin. In contrast, individual channel bodies have yet to be mapped inland, and our observations in the coastal section (Davies and Gibling 2003; Rygel 2005) indicate that most channel-sandstone bodies are lensoidal and discontinuous. Although thick intervals of coarser and finer strata tend to be mappable within the basin at the formation scale (Shaw 1951b), the lensoidal nature of and relative similarity between channel bodies in the Joggins and Springhill Mines formations makes the uppermost limestone a more useful lithostratigraphic surface.

The Joggins Formation as redefined has a total thickness of $915.5 \mathrm{~m}$. Logan (1845) recorded this interval as $2533^{\prime} 7^{\prime \prime}$ (772 $\mathrm{m})$, a discrepancy likely resulting from the speed at which he measured the section (Rygel and Shipley 2005).

\section{Members}

The Coal Mine Point and Bells Brook members of the Joggins Formation were not formally defined by Ryan and Boehner (1994) and are abandoned here. The boundary between them was designated as the top of a sandstone just south of Bells Brook, but this bed is not prominent and there is no indication that it is mappable. Between Lower Cove and Coal Mine Point, Duff and Walton (1973) designated informal lower, middle and upper beds, and Davies and Gibling (2003) and the present authors recognize informal cycles 16 to $212 \mathrm{~m}$ thick, the bases of which are located at prominent flooding levels marked by limestone, coal and grey platy shale with siderite nodules (Appendix A). Some coal seams at cycle bases are mappable inland (Goudge 1945; Copeland 1959) and some cycles or groups of cycles could in the future merit member status if they prove to be extensive.

\section{AGE OF THE JOGGINS FORMATION}

The formation has been dated on the basis of palynology as late Langsettian (Dolby 1991). Recent investigation and taxonomic revision of the macroflora suggest that the strata are most probably early Langsettian (Utting and Wagner 2005), and the proximity of the Namurian-Westphalian boundary is suggested by the presence of late Namurian floral elements. 


\section{THE STRATIGRAPHIC SECTION}

The stratigraphic section (Fig. 5; Appendix A) was measured bed-by-bed with centimetre-scale resolution. Although measured at the base of the accessible cliff, the section represents the exposed cliff face more broadly and records lateral changes in thickness of channel bodies and crevasse splays evident at the time of measurement. Figure 6 shows the stratigraphic level in the section (in metres above the base of the Joggins Formation) for distinctive beds that protrude from the adjacent tidal platform as resistant bodies, long known as "reefs". Fine-grained beds, limestones and sharp-based sandstones are generally continuous across the exposure area, but the numerous lensoidal channel bodies exposed only in the foreshore are not represented in the measured section. Considerable difficulty was encountered in measuring an accurate section through the former mining areas on the Joggins Seam due to waste heaps and the removal of the coal seams. We record present exposures in this interval ( $800 \mathrm{~m}$ to $870 \mathrm{~m})$, leaving Logan's section - which was measured prior to major coal extraction - as a more complete representation. Red and drab intervals are recorded to the left of the column; these colour designations are highly generalized, and drab intervals in particular show wide variation from dark to light grey and green. Most channel sandstones are grey-brown regardless of their association, and their colour is typically shown on the $\log$ as similar to the strata above and below.

The section is divided into 14 cycles (Fig. 7), the bases of which are marked by limestone, coal or fossiliferous shale. The cycles are divided in turn into stratal intervals that belong to the open-water, poorly drained floodplain, and well drained floodplain facies assemblages (Davies and Gibling 2003), the main features of which are summarized briefly below. In the cycles, the three assemblages typically succeed each other upwards, although the open-water facies assemblage is not represented in some cycles.

\section{FACIES ASSEMBLAGES AND FOSSIL GROUPS}

\section{Open-water facies assemblage}

This assemblage represents major flooding events, some of which probably inundated most of the western Cumberland Basin. Especially good examples in the lower part of the formation (cycles 2-4) are represented by a thin coal overlain by a dark limestone up to $1 \mathrm{~m}$ thick, which is overlain in turn by several metres of grey siltstone capped abruptly or gradationally by sandstone. The limestones are well cemented and stand out on the foreshore. They are locally termed "clam coals" because of their dark colour and the abundance of bivalves with accessory ostracodes, spirorbids, arthropods, disarticulated fish and plant fragments.

The overlying siltstones are laminated and platy weathering, and contain discoidal siderite nodules. The siltstones contain bivalves and ostracodes (generally confined to discrete levels), as well as drifted plant material. Agglutinated foraminifera were obtained from some samples (Archer et al. 1995). Capping the siltstones are sharp-based, sheet-like sandstones a few metres thick, which extend across the cliff and foreshore and are characterized by planar bedding and a flaggy appearance. In a few instances, they comprise overlapping mounds up to 100 $\mathrm{m}$ in apparent width. The sandstones contain unidirectional ripple cross-lamination, local mud drapes, and lineated plane beds, with wave ripples and rare hummocky cross-stratification indicating wave activity. Trace fossils include delicate grazing and walking traces (Archer et al. 1995) and, less commonly, resting traces (for example of limulids). A few channel bodies cut the planar sandstones, with which they are evidently closely associated. The topmost coarser beds contain roots, which mark the re-establishment of subaerial conditions after the initial flooding event.

The assemblage represents the establishment across the basin of a restricted-marine gulf, perhaps similar to the modern Baltic Sea in its partially enclosed nature and variable but generally low salinity (Grasshoff 1975). Open-marine faunal elements have not been observed, but the presence of certain taxa of bivalves, ostracodes, foraminifera and trace fossils suggest at least brackish conditions (Bell 1914; Duff and Walton 1973; Archer et al. 1995; Skilliter 2001; Tibert and Dewey 2005). Strontium isotope data from fish material also suggest marine influence (Calder 1998), although mineralogical and geochemical data from some bivalve shells are consistent with a freshwater setting (Brand 1994). During some flooding events at cycle bases, the presence of a basal coal suggests that peat formation initially kept pace with rising water level. When the rate of sea-level rise exceeded that of peat accumulation, the area was transformed into a shallow bay where faunal-concentrate layers accumulated. The upward change to siltstone indicates the renewed advance of the coastal plain as the rate of sea-level rise decreased. Progradation culminated in shallow-water sands that represent thin shorefaces and small delta lobes derived from the associated channels. Wave activity was prominent, but sedimentological evidence for tidal influence is restricted to mud drapes at a few levels (Skilliter 2001).

Drifted lycopsid plants predominate in the basal limestones, whereas overlying siltstones and sandstones contain a mixed suite of drifted gymnosperms (cordaitaleans), sphenopsids (primarily calamiteans), pteridosperms and putative progymnosperms (Falcon-Lang 2003a). The high proportion of progymnosperms and gymnosperms suggests that the basin floor was almost entirely drowned, greatly reducing the area of coastal swamps. Under these conditions, elements of the upland vegetation (Falcon-Lang and Scott 2000) brought to the sea by rivers were preferentially concentrated in the siltstones (an example of the "Neves Effect" of Chaloner 1958). The presence of stigmarian roots within some limestone beds points to near emergent, shallow conditions in some cases, and maximum water depth during deposition of open-water facies was probably only a few metres to a few tens of metres. 


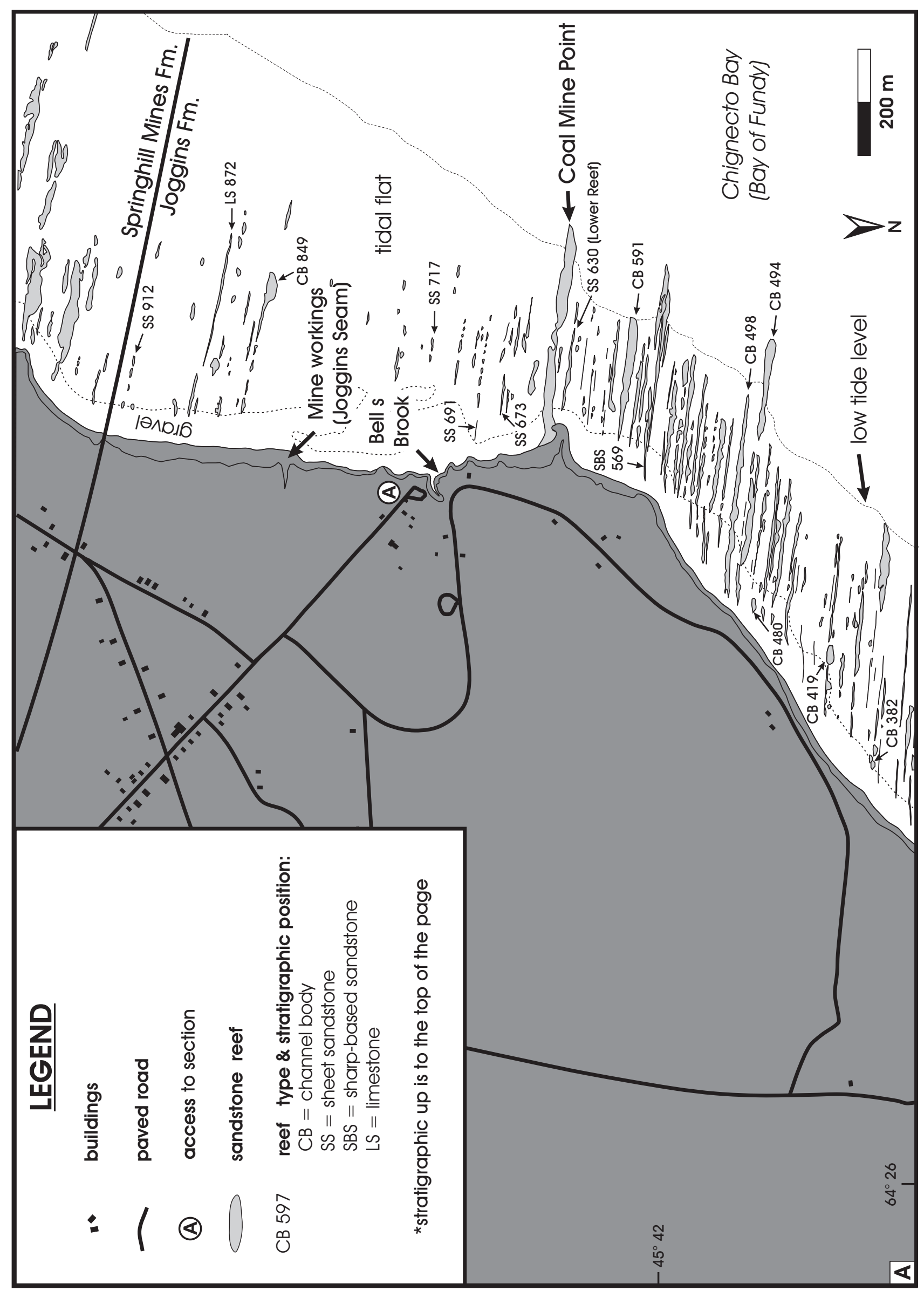




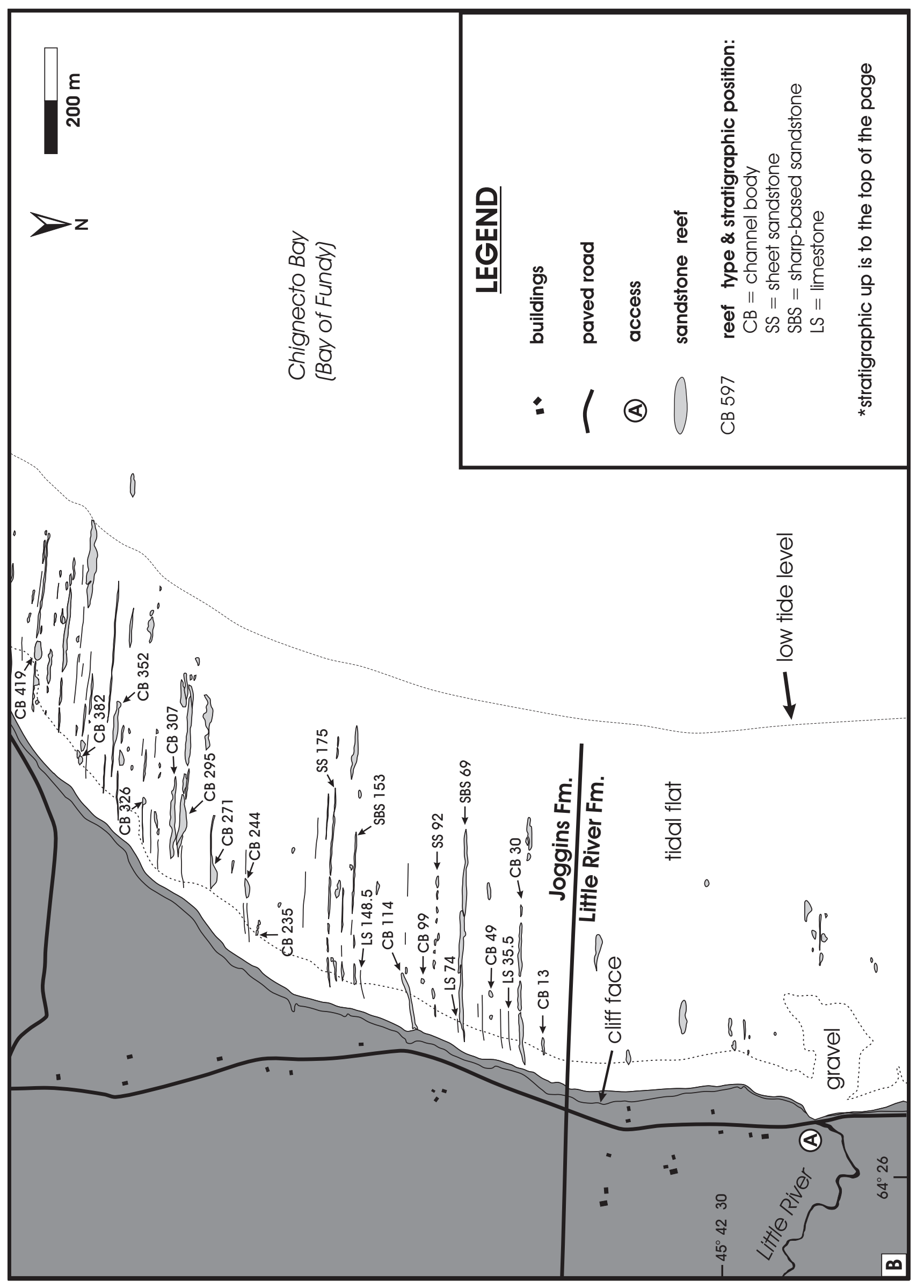

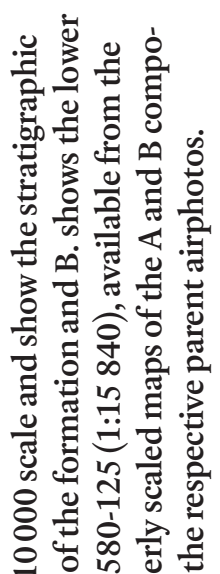
ํㅜㄴ원

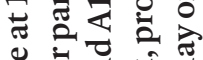

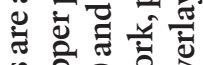
औ

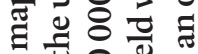
둥의

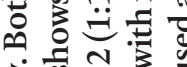

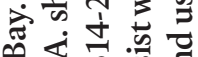
$0 \dot{0}$ 究

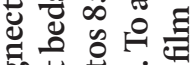
맘형 บิ

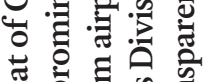
远政

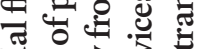

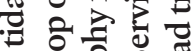
કै

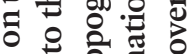

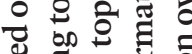
象苛

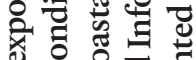

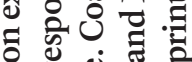

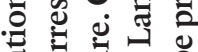
氙 ह 훙 . ॠ

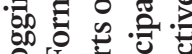
일

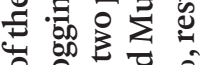
¿ औ류

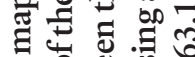
융 눈

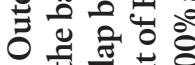
을 훈을 ปิ ते ปิ ४

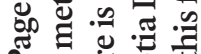
E. 0. 


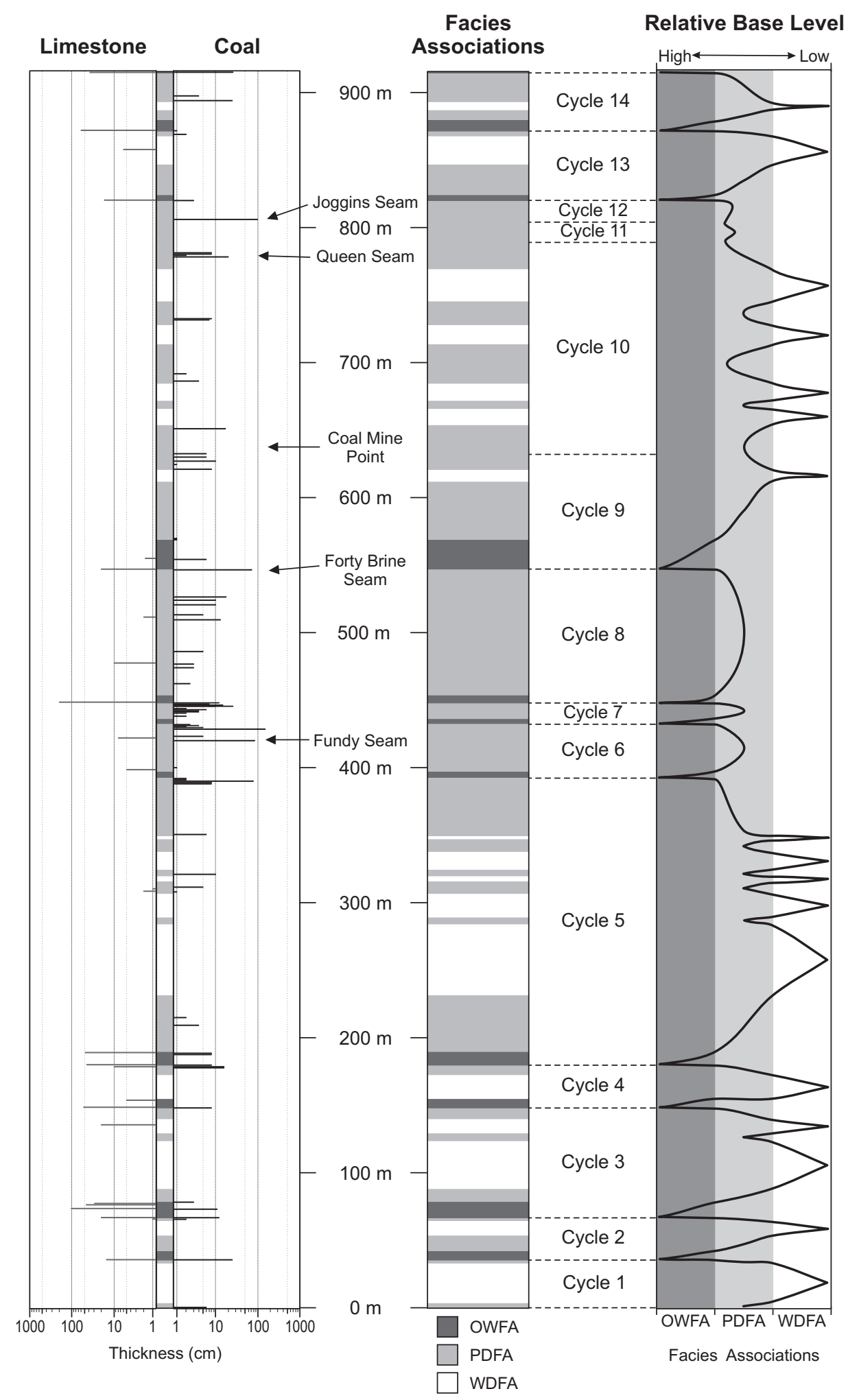

Fig. 7 Summary log for the Joggins Formation, showing cycles, facies assemblages, position and thickness of coal and limestone beds, and relative base-level curve. 


\section{Poorly drained floodplain assemblage}

Joggins is justifiably famous for its poorly drained floodplain deposits, which contain the spectacular fossil forest horizons. Sandstone and green/grey mudstone (commonly intensively rooted), are accompanied by coal, carbonaceous shale and minor limestone, with siderite nodules. Bivalves and ostracodes are generally less common than in the open-water assemblage. The assemblage includes thin grey carbonaceous shales that separate red beds near cycle tops from coal and limestone at the base of the next cycle.

Especially prominent are sheet-like, heterolithic units of sandstone and mudstone, several metres thick, which extend across the cliffs and foreshore and contain many entombed erect trees. Splendid examples include two forested intervals below the Fundy Seam (404-420 m; Calder et al. in press), two intervals just below the Forty Brine Seam (539-546 m) and the lower reef just north of Coal Mine Point (628-630 m). Charles Lyell was struck by the preserved height of the trees, which he estimated to be up to $7.6 \mathrm{~m}$ tall (Lyell 1842, 1845). The maximum height observed over the past three decades has been $6 \mathrm{~m}$ (Calder et al. in press). Vegetation includes abundant lycopsids and sphenopsids in situ (Falcon-Lang 1999; Calder $e t$ al. in press) with a compression macrofloral record comprising cordaitalean gymnosperms, pteridosperms, ferns and putative progymnosperms (Calder et al. in press). Many standing trees are bordered by scour fills of sandstone up to $2 \mathrm{~m}$ thick with centroclinal (inward dipping) cross-stratification, and suites of large sandy mounds (vegetation shadows) are common (Rygel et al. 2004).

Within this assemblage, Lyell and Dawson made their remarkable discovery of fossils within tree trunks, mainly from the lower reef ("Lesser Reef" of Dawson 1882) at Coal Mine Point. The tree-stump fauna is highly diverse, including eleven tetrapod genera, abundant coprolites, and a variety of invertebrates - land snails (Dendropupa), millipedes, arthropod fragments, and calcareous shells of the annelid Spirorbis (Carroll et al. 1972). Charcoal fragments are abundant within and adjacent to some trunks, testifying to wildfires that swept the forests (Falcon-Lang 1999). The organisms may have taken refuge within hollow trees or may have become entombed accidentally, and some fragments may have been swept in by floods (Lyell and Dawson 1853; Carroll et al. 1972; Scott 2001).

The heterolithic units are closely associated with narrow channel bodies up to $3 \mathrm{~m}$ thick. A few much larger channel bodies are also present in the assemblage. One large channel body at $580 \mathrm{~m}$ has incised $9 \mathrm{~m}$ through rooted grey mudstone and contains two vertically stacked storeys. The major sandstone "reef" at Coal Mine Point (637-648 m) is a channel body that contains trough cross-beds, scroll-bar forms and lateral accretion surfaces (Rygel 2005). This channel body contains especially spectacular examples of Diplichnites (large trackways attributed to the arthropod Arthropleura: Ferguson 1975).

Many of the coal groups (marked on the section in Appendix A) lie within this assemblage, which includes the main economic seams of the formerly worked Joggins-Chignecto Coalfield: most notably the Fundy (coal 29a), Forty Brine (coal 20), Kimberly (coal 14), Queen (coal 8) and Joggins (coal 7) seams. The bituminous coals are sulphur-rich (Copeland 1959; Skilliter 2001) with prominent mudstone partings and locally high concentrations of $\mathrm{Zn}, \mathrm{Pb}$ and As (Hower et al. 2000).

The strata were deposited in wetlands akin to those of the modern Mississippi Delta (Coleman and Prior 1980; Tye and Coleman 1989), although the geomorphic form of the coastal system is not known. Small distributary channels traversed the coastal plain and brought sand and mud to the adjacent fresh to brackish bays during repeated flood events, depositing characteristically heterolithic sediment as interdistributary crevasse splays and bay fills. These sedimentation events entombed the standing trees (Calder et al. in press) and created scour hollows and vegetation shadows around the trunks (Rygel et al. 2004). At the level of the upper Fundy forest ( $419 \mathrm{~m}$ level in Appendix A), thin sandstone sheets can be traced from the margins of channel bodies on the tidal platform into scour fills around standing trees exposed in the cliffs. The forests were affected by wildfires that may have been instrumental in hollowing out the trunks and providing shelter for early tetrapods and other organisms. The channel body at the $580 \mathrm{~m}$ level is interpreted as a large distributary channel, based on its incised nature and aggradational style, whereas the Coal Mine Point channel body represents a meandering river that advanced over bayfills, much as the modern Atchafalaya River of Louisiana advanced rapidly once it had filled Atchafalaya Bay (Tye and Coleman 1989). Thin poorly drained intervals at cycle tops represent incipient drowning of the coastal zone prior to the main transgression.

The coals represent planar (groundwater-fed) mires (Hower et al. 2000; Calder et al. in press) where, for prolonged periods, peat accumulated away from detrital supply, although floods periodically generated muddy partings. Several economic seams cap heterolithic units or channel bodies, suggesting that the precursor peat accumulated in freshwater settings following abandonment of a local distributary. These thick coals may be the updip equivalent of marine flooding events, and the high sulphur levels of many coals suggest that marine, sulphate-rich waters influenced the peats, probably after the mires were drowned by sea-level rise. Many drab mudstones are hydromorphic paleosols that formed under variable redoxymorphic conditions, and red and red/grey mottled intervals testify to episodes of soil formation under oxidizing conditions (Smith 1991). The 595-612 m interval of cycle 9 contains stratified red and grey mudstone without coal or invertebrate fossils, suggesting that oxidized mud was washed into clastic-dominated lakes.

\section{Well drained floodplain assemblage}

This predominantly red bed assemblage comprises red mudstone and sandstone, with minor grey mudstone, rare coal and ostracode-bearing limestone. Although not highly fossiliferous, these strata have recently yielded some unusual 
fossil discoveries (Hebert and Calder 2004), as outlined below. Cycle 4 contains an especially thick red bed interval.

Channel bodies are narrow and up to $6 \mathrm{~m}$ thick with an aggradational style of filling, and in places several bodies lie at the same stratigraphic level in the cliffs (Rygel 2005). Most are associated with heterolithic sheets of sandstone and mudstone that typically thin away from the channel bodies and represent levee and crevasse splay complexes. The channels are filled with grey and red sandstone and mudstone, with local conglomerates composed of reworked carbonate (paleosol) fragments. Within cycles 1 and 3, some large channel bodies contain smaller channel fills, suggesting that the bodies are small dryland valleys. The red muds are poorly stratified and contain scattered calcareous nodules, although petrocalcic horizons were not observed.

Standing trees are restricted to poorly preserved stump casts, and narrow hollow fills with abundant underlying roots marking the former positions of trees, since decayed (Rygel et al. 2004). Charcoal and other floral remains in channel bodies are dominated by cordaitaleans, with minor pteridosperms, sphenopsids and lycopsids - the minor constituents typically confined to channel-margin situations (Falcon-Lang 1999, 2003b; Falcon-Lang and Scott 2000). One channel body at 270-274 m, known informally as the "Hebert beds", contains abundant charcoal as well as tetrapod material, shells up to 23 $\mathrm{cm}$ long of the unionid bivalve Archanodon, and land snails (Dendropupa) (Falcon-Lang et al. 2004a; Hebert and Calder 2004). Other channel bodies have yielded large arthropod trackways (Diplichnites).

The assemblage represents the alluvial plain of a seasonal dryland traversed by suites of narrow channels that probably had an anastomosing planform (Rygel 2005), as indicated by multiple, narrow channels at similar levels connected by sheet sandstones ("ribbon tiers" of Kraus and Wells 1999). The setting may have resembled that of the Channel Country of Australia with its dryland anastomosing systems and water holes (Gibling et al. 1998); Rust et al. (1984) also drew on the Channel Country in interpreting the overlying Springhill Mines Formation. The red floodplain muds are immature, cumulative paleosols that formed under a humid seasonal climate (Smith 1991). The abundance of cordaitalean charcoal in some dryland channels suggests that the seasonally dry floodplains were covered with a fire-prone and ecologically stressed assemblage dominated by gymnosperms (Falcon-Lang 2003b; Falcon-Lang et al. 2004a). Riparian (channel-margin) settings permitted the local growth of vegetation more akin to the wetlands, and wildfires were common, perhaps promoted by elevated levels of atmospheric oxygen (Robinson 1991). The unusual biota preserved within the "Hebert beds" suggest that the parent channels provided intermittent water holes where organisms continued to flourish during seasonal low-stage flow or more prolonged droughts (Falcon-Lang et al. 2004a).

\section{FORMATION-SCALE TRENDS}

\section{Cyclic patterns}

The 14 cycles recognized in the $915.5 \mathrm{~m}$ of the Joggins Formation range in thickness from 16 to $212 \mathrm{~m}$, averaging $65 \mathrm{~m}$. Nine cycles are 16 to $52 \mathrm{~m}$ thick, three are 52 to $99 \mathrm{~m}$ thick, and the remaining two are $158 \mathrm{~m}$ and $212 \mathrm{~m}$ thick, respectively. Facies distribution was used to construct a relative base-level curve for the formation (Davies and Gibling 2003; Fig. 7). Unfortunately, the present lack of firm biostratigraphic boundaries and absolute dates for the section precludes the determination of cycle durations and accumulation rates.

Relatively straightforward facies patterns are evident in cycles 1 to 4 and in the basal part of cycle 5 . These intervals show a systematic upward succession from open-water facies, which mark major transgressions, to poorly drained and well drained facies, marking regressions. At some levels, thin occurrences of poorly drained facies below open-water intervals herald the base of the next cycle, denoting the onset of base-level rise. Limestones and platy siltstones are prominent, coals are thin and mainly underlie limestones, and the prominent sharpbased sandstones that cap open-water deposits contain many trace fossils. Cycle 5 constitutes the most prolonged period of red bed accumulation, with alternate periods of poorly and well drained conditions and some thin coals in the upper $80 \mathrm{~m}$.

The most marked and sustained lithological change within the formation is the relatively abrupt change from well drained to poorly drained floodplain deposits at the base of cycle 6 (Fig. 7), with a suite of prominent coals; future mapping inland may provide justification for identification of a member boundary at this level. Cycles 6 to 8 are of moderate thickness, and usher in a period when the area was dominated by coastal wetlands (represented by the poorly drained assemblage), with only thin intervals of open-water deposits. Coals are numerous and thick, and many of the most prominent fossil forests are found in this interval (Calder et al. in press). Limestones are generally scarce, apart from a thick bed at the base of cycle 8. Cycle 9 commences with a well developed occurrence of open-water facies above the Forty Brine Seam (Skilliter 2001), with limestones, mud drapes, trace fossils (Archer et al. 1995), and a large distributary channel body, passing upward into probable lacustrine deposits of stratified red and grey beds.

Cycle 10 (158 m thick) marks the start of a $200 \mathrm{~m}$ interval of alternate poorly drained and well drained deposits without open-water sections and limestones (cycles 10-12). Prominent sets of fossiliferous carbonaceous shales (cycle 10) or thick coals (Queen and Joggins seams, cycles 11 and 12) mark cycle bases, but several thin coals delineate minor transgressions within the numbered cycles. Limestones mark the base of cycles 13 and 14 and the Joggins / Springhill Mines formation contact.

Following the abrupt onset of wetland conditions at its base, the Joggins Formation records a punctuated set of advances and retreats of the coastal zone (Fig. 7). A long-term balance seems to have been maintained between accommodation creation 
and sediment supply, such that the study area remained close to the coastal zone for much of Joggins Formation time, with periods of more sustained open-water, wetland or dryland conditions. Thick limestones and thick coals tend to be mutually exclusive (Fig. 7): thin coals underlie many limestones, but thick coals rarely have limestone caps, the most notable exception being the Forty Brine Seam (coal 20). This pattern probably reflects variations in the magnitude and rate of baselevel rise. Large base-level rises would tend to flood much of the Cumberland Basin, resulting in reduced sediment flux to open-water areas and the accumulation of fossil-concentrate limestone. Rapid base-level rise would tend to outpace the rate of peat accumulation, resulting in thin peats only. In contrast, thick peats (coals) probably accumulated where modest or slow base-level rise caused prolonged freshwater ponding inland of transgressive shorelines (Kosters and Suter 1993). A rheotrophic (groundwater-influenced), planar character is the hallmark of the coals of the Joggins Formation (Hower et al. 2000; Calder et al. in press).

Sand accumulated preferentially in the poorly drained floodplain assemblage, where coastal bays formed repositories for coarse detritus. In these areas, sand deposition was strongly focused into sheets, scour fills and vegetation shadows where forested landscapes slowed overtopping flood waters (Rygel et al. 2004). In contrast, shoreface and delta-lobe sands of the open-water assemblage are relatively thin, and dryland alluvial plains of the well drained assemblage include thick mud intervals, with sands restricted to small channels, levees and splays.

\section{Sequence stratigraphy}

Many Carboniferous cycles (or cyclothems) reflect sea-level fluctuations in the order of tens of metres in amplitude caused by the accumulation and melting of ice sheets in high southern latitudes (Crowley and Baum 1991; Maynard and Leeder 1992; Soreghan and Giles 1999). Glacioeustasy in Carboniferous basins has commonly generated stacked Exxon-type sequences with prominent sequence boundaries, valley fills, maximum flooding surfaces and systems tracts (Hampson et al. 1999; Gibling et al. 2004). Such expressions of glacioeustasy may be modified under conditions of unusually rapid subsidence, as at Joggins, where the record of sea-level fall may be suppressed and the record of sea level rise may be strongly augmented, rendering the basin susceptible to basin-wide flooding events marked by fauna-rich horizons. At Joggins in the western Cumberland Basin, rapid subsidence reflects the extensional basin setting, coupled with active withdrawal of Windsor salt (Waldron and Rygel 2005). In consequence, the Joggins cycles display what we consider to be a "tectonically controlled architecture" characterized by multiple flooding surfaces (Davies and Gibling 2003), including coal and fossiliferous limestone at cycle bases that mark important episodes of sea-level rise. The overlying strata lack clear evidence for sea-level fall such as profound valley incision or well developed paleosols, although sharp- based shoreface and delta-lobe sandstones may reflect in part modest falls of sea-level (similar to those documented by Plint 1988). Large channel bodies appear to represent distributary channels and meandering rivers within a coastal plain setting, rather than recording profound basinward facies shifts that could have emplaced proximal (braided or low-sinuosity) river deposits over marine deposits. Small valley fills in cycles 2 and 3 appear to lie within red bed intervals, and need not imply major basinward shifts of facies belts linked to base-level lowering. The Joggins cycles may record glacial-interglacial transitions manifested in an equatorial setting, periods of varied subsidence rate as faults moved and salt migrated, variations in sediment flux, or combinations of all three. However, regardless of the ultimate cause of the cycles, their unusual architectural features are inferred to reflect extremely rapid subsidence, in accord with observations in other high-subsidence settings worldwide (Davies and Gibling 2003).

In the absence of sequence boundaries, the Joggins cycles can be categorized as parasequence sets, in which the predominant coastal-plain facies are composed of numerous thin parasequences and bounded by flooding surfaces marked by limestones, coals and carbonaceous shales. Thin drab intervals at cycle tops mark retrogradational parasequence sets that culminated in profound flooding at the start of the overlying cycle. As coastal rivers re-advanced, thick progradational parasequence sets accumulated where tropical wetland deposits filled marine embayments, until a dryland alluvial plain was established. Thereafter, alluvial red beds accumulated, flooding surfaces become fewer and less prominent, and trends of pro-, retro- or aggradation are difficult to establish.

Because subsidence was so rapid, a remarkably complete record of environments and the organisms that inhabited them is preserved in the Joggins cycles. In particular, prolonged periods of wetland conditions, during which sedimentation kept pace with subsidence, promoted the repeated generation and burial of forests at many levels (Waldron and Rygel 2005).

\section{CONCLUSIONS}

The Joggins Formation in the famous fossil cliffs along Chignecto Bay, Nova Scotia, has been completely remeasured for the first time since the mid 1800s. We present a visual log of $915.5 \mathrm{~m}$ of strata and describe revised formation boundaries (formalized in Calder et al. 2005). The formation comprises stacked transgressive-regressive cycles that typically commence with open-water facies with a restricted-marine fauna, overlain by prograding coastal and alluvial deposits. The main levels of standing trees, predominantly lycopsids, were entombed where distributary channels brought sand into coastal wetlands, and some trees contain tetrapod and invertebrate fossils. Fire-prone cordaitalean (gymnosperm) forests covered the alluvial plains and basin-margin uplands. The cycles may reflect tectonic or glacioeustatic events, or variations in sediment flux. Within the cycles, the predominance of flooding surfaces and the apparent 
absence of lowstand exposure surfaces reflect rapid subsidence of the Cumberland Basin, controlled by active basin-margin faults and salt withdrawal.

Joggins is an unusual geological locality, and the many scientists, university and school groups, and enthusiastic members of the public who visit the cliffs each year bear testimony to the enduring fascination of this special site. We offer here an illustrated log and foreshore map of the Joggins Formation, along with a brief summary of especially interesting features of the strata, to encourage continued interest in the rocks and fossils. Given the huge and frequently overwhelming amount of rock on display, we hope that the log will serve as a simple guide to visitors with some knowledge of geology, as well as allowing specialists to mark precisely the locations of new fossil discoveries. As Lyell and Dawson realized more than 150 years ago, Joggins is all about ancient landscapes inhabited by remarkable plants and animals, for the fossils are at their most compelling when we can imagine them in the environments where they lived more than 300 million years ago.

\section{ACKNOWLEDGMENTS}

We are most grateful to Peter Giles and Sue Johnson for their thoughtful comments on the manuscript, to Rob Fensome for editorial suggestions, and to Howard Falcon-Lang, Brian Hebert, Andrew Henry, Adrienne Rygel, Don Reid and Leonard Wilson for assistance and discussion. M. Gibling acknowledges funding from the Natural Sciences and Engineering Research Council of Canada (NSERC Grant Number 13354), the Petroleum Research Fund of the American Chemical Society (Grant 36917-AC8), and a research grant from Imperial Oil (Grant IO182DAL). M. Rygel's research was supported by a Killam Predoctoral Scholarship at Dalhousie University and grants from the American Association of Petroleum Geologists, the Geological Society of America (GSA), and the GSA Coal Geology Division (Medlin Award).

\section{REFERENCES}

Archer, A.W., CAlder, J.H., Gibling, M.R., NAYlor, R.D., REID, D.R., \& Wightman, W.G. 1995. Invertebrate trace fossils and agglutinated foraminifera as indicators of marine influence within the classic Carboniferous section at Joggins, Nova Scotia, Canada. Canadian Journal of Earth Sciences, 32, pp. 2027-2039.

BELL, W.A. 1912. Joggins Carboniferous section of Nova Scotia. Geological Survey of Canada Summary Report, 1911, pp. 328-333.

BELL, W.A. 1914. Joggins Carboniferous section, Nova Scotia. Geological Survey of Canada, Summary Report, 1912, pp. 360-371.

BELL, W.A. 1943. Carboniferous rocks and fossil floras of northern Nova Scotia. Geological Survey of Canada, Memoir 238, 119 p.
BeLt, E.S. 1964. Revision of Nova Scotia middle Carboniferous units. American Journal of Science, 262, pp. 653-673.

BRAND, U. 1994. Continental hydrology and climatology of the Carboniferous Joggins Formation (lower Cumberland Group) at Joggins, Nova Scotia: evidence from the geochemistry of bivalves. Palaeogeography, Palaeoclimatology, Palaeoecology, 106, pp. 307-321.

Brown, R., \& SMith, R. 1829. Geology and mineralogy. In A historical and statistical account of Nova Scotia, Volume 2. Edited by T. C. Haliburton. Joseph Howe, Halifax, pp. 414-453.

CALDER, J.H. 1994. The impact of climate change, tectonism and hydrology on the formation of Carboniferous tropical intermontane mires: the Springhill coalfield, Cumberland basin, Nova Scotia. Palaeogeography, Palaeoclimatology, Palaeoecology, 106, pp. 323-351.

Calder, J.H. 1998. The Carboniferous evolution of Nova Scotia. In Lyell, the past is the key to the present. Edited by D. J. Blundell and A. C. Scott. London, Geological Society, Special Publication 143, pp. 261-302.

CALDER, J.H. 2003. The fossil cliffs of Joggins: coal age Galapagos. Field trip guidebook for the 2003 Energy and Mines Ministers' Conference, Halifax, Nova Scotia, September 20, 2003, 21 p.

CAlder, J.H., Rygel, M.C., Ryan, R.J., Falcon-Lang, H.J., \& Hebert, B.L. 2005. Stratigraphy and sedimentology of early Pennsylvanian red beds at Lower Cove, Nova Scotia, Canada: the Little River Formation with redefinition of the Joggins Formation. Atlantic Geology, 41, pp. 143-167.

Calder, J.H., Gibling, M.R., Scott, A.C., Davies, S.J., \& Hebert, B.L. in press. A fossil lycopsid forest succession in the classic Joggins section of Nova Scotia: paleoecology of a disturbance-prone Pennsylvanian wetland. In Wetlands through time. Edited by S. Greb and W. DiMichele. Geological Society of America Special Paper 399.

Carroll, R.L., Belt, E.S., Dineley, D.L., Baird, D., \& McGregor, D.C. 1972. Vertebrate paleontology of eastern Canada. XXIV International Geological Congress, Montreal, Excursion A59, pp. 64-80.

Chaloner, W.G. 1958. The Carboniferous upland flora. Geological Magazine, 95, pp. 261-262.

Coleman, J.M., \& Prior, D.B. 1980. Deltaic sand bodies. American Association of Petroleum Geologists, Education Course Note Series, v. 15: Tulsa, Oklahoma, 171 p.

Copeland, M.J. 1959. Coalfields, west half Cumberland County, Nova Scotia. Geological Survey of Canada, Memoir 298, 89 p.

Crowley, T.J., \& BAum, S.K. 1991. Estimating Carboniferous sea-level fluctuations from Gondwanan ice extent. Geology, 19, pp. 975-977.

DARWIN, C. 1859. The origin of species by means of natural selection. $1^{\text {st }}$ edition. Murray, London, $513 \mathrm{p}$.

Davies, S.J., \& Gibling, M.R. 2003. Architecture of coastal and alluvial deposits in an extensional basin: the Carboniferous Joggins Formation of eastern Canada. Sedimentology, 50, pp. 415-439. 
Dawson, J.W. 1854. On the coal measures of the South Joggins, Nova Scotia. Quarterly Journal of the Geological Society of London, v. 10, pp. 1-42.

DAwson, J.W. 1855. Acadian geology. An account of the geological structure and mineral resources of Nova Scotia, and portions of the neighbouring provinces of British America. $1^{\text {st }}$ Edition. Oliver and Boyd, Edinburgh, $388 \mathrm{p}$.

DAwson, J.W. 1868. Acadian geology. The geological structure, organic remains, and mineral resources of Nova Scotia, New Brunswick, and Prince Edward Island. $2^{\text {nd }}$ Edition. Macmillan, London, $694 \mathrm{p}$.

DAwson, J.W. 1878. Acadian geology. The geological structure, organic remains, and mineral resources of Nova Scotia, New Brunswick, and Prince Edward Island. $3^{\text {rd }}$ Edition. Macmillan, London, $825 \mathrm{p}$.

Dawson, J.W. 1882. On the results of recent explorations of erect trees containing animal remains in the coal formation of Nova Scotia. Philosophical Transactions of the Royal Society of London, 173, pp. 621-659.

Dolby, G. 1991. The palynology of the western Cumberland Basin, Nova Scotia. Halifax, Nova Scotia, Nova Scotia Department of Mines and Energy, Open File Report 91-006, $39 \mathrm{p}$.

Duff, P.M., \& Walton, E.K. 1973. Carboniferous sediments at Joggins, Nova Scotia. In Seventh International Congress on Carboniferous Stratigraphy and Geology, Compte Rendu, 2, pp. 365-379.

FalCon-LANG, H.J. 1999. Fire ecology of a Late Carboniferous floodplain, Joggins, Nova Scotia. Journal of Geological Society of London, 156, pp. 137-148.

Falcon-LANG, H.J. 2003a. Response of Late Carboniferous tropical vegetation to transgressive-regressive rhythms at Joggins, Nova Scotia. Journal of Geological Society of London, 160, pp. 643-647.

FaLCon-Lang, H.J. 2003b. Late Carboniferous tropical dryland vegetation in an alluvial-plain setting, Joggins, Nova Scotia, Canada. Palaios, 18, pp. 197-211.

Falcon-Lang, H.J., \& CAlder, J.H. 2004. UNESCO World Heritage and the Joggins cliffs of Nova Scotia. Geology Today, 20, pp. 139-143.

Falcon-LANG, H.J., \& ScotT, A.C. 2000. Upland ecology of some Late Carboniferous cordaitalean trees from Nova Scotia and England. Palaeogeography, Palaeoclimatology, Palaeoecology, 156, pp. 225-242.

Falcon-Lang, H.J., Rygel, M.C., Gibling, M.R., \& Calder, J.H. 2004a. Early Pennsylvanian waterhole deposit and its fossil biota in dryland alluvial plain setting, Joggins, Nova Scotia. Journal of Geological Society of London, 161, pp. 209-222.

Falcon-Lang, H.J., Calder, J.H., Gibling, M.R., Rygel, M.C., \& Davies, S.J. 2004b. A dance to the music of time. Geoscientist, 14, pp. 4-9.

Ferguson, L. 1975. The Joggins section. Maritime Sediments, 11, pp. 69-76.

Gesner, A. 1836. Remarks on the geology and mineralogy of Nova Scotia. Gossip and Coade, Halifax, NS, 272 p.
Gibling, M.R., \& Kalkreuth, W.D. 1991. Petrology of selected carbonaceous limestones and shales in Late Carboniferous coal basins of Atlantic Canada. International Journal of Coal Geology, 17, pp. 239-271.

Gibling, M.R., Nanson, G.G., \& Maroulis, J.C. 1998. Anastomosing river sedimentation in the Channel Country of central Australia. Sedimentology, 45, pp. 595-619.

Gibling, M.R., SAunders, K.I., Tibert, N.E., \& White, J.A. 2004. Sequence sets, high-accommodation events and the coal window in the Carboniferous Sydney Basin, Atlantic Canada. In Sequence stratigraphy, paleoclimate, and tectonics of coal-bearing strata. Edited by S. Greb and R.A. Gastaldo. American Association of Petroleum Geologists, Studies in Geology, 51, pp. 169-197.

Goudge, M.G. 1945. Joggins-River Hebert coal district (a review). Nova Scotia Department of Mines Annual Report for 1944, pp. 152-182.

GrasshofF, K. 1975. The hydrochemistry of landlocked basins and fjords. In Chemical Oceanography, Volume 2. $2^{\text {nd }}$ Edition. Edited by J.P. Riley and J. Skirrow. Academic Press, New York, pp. 456-597.

Hampson, G.J., Davies, S.J., T., E., Flint, S.S., \& Stollhofen, H. 1999. Incised valley fill sandstone bodies in Upper Carboniferous fluvio-deltaic strata: recognition and reservoir characterization of southern North Sea analogues. Petroleum Geology of Northwest Europe: Proceedings of the 5th Conference, pp. 771-788.

Hebert, B.L., \& Calder, J.H. 2004. On the discovery of a unique terrestrial faunal assemblage in the classic Pennsylvanian section at Joggins, Nova Scotia. Canadian Journal of Earth Sciences, 41, pp. 247-254.

Hower, J.C., Calder, J.H., Eble, C.F., Scott, A.C., RobERTSON, J.D., \& Blanchard, L.J. 2000. Metalliferous coals of the Westphalian A Joggins Formation, Cumberland Basin, Nova Scotia, Canada: petrology, geochemistry, and palynology. International Journal of Coal Geology, 42, pp. 185-206.

JACKSON, C.T., \& AlgER, F. 1828. A description of the mineralogy and geology of a part of Nova Scotia. American Journal of Science, 14, pp. 305-330.

Kelley, D.G. 1967. Some aspects of Carboniferous stratigraphy and depositional history in the Atlantic Provinces. In Collected papers on geology of the Atlantic region. Edited by E.R.W.Neale and H.Williams. Geological Association of Canada, Special Paper 4, pp. 213-228.

Kosters, E.C., \& Suter, J.R. 1993. Facies relationships and systems tracts in the Late Holocene Mississippi delta plain. Journal of Sedimentary Petrology, 63, pp. 727-733.

Kraus, M.J., \& Wells, T.M. 1999. Recognizing avulsion deposits in the ancient stratigraphic record. In Fluvial Sedimentology VI. Edited by N.D.Smith and J.Rogers. International Association of Sedimentologists Special Publication 28, pp. 251-268.

LogAN, W.E. 1845. A section of the Nova Scotia coal measures as developed at Joggins on the Bay of Fundy, in descending order, from the neighbourhood of the west Ragged Reef 
to Minudie, reduced vertical thickness. Appendix W: Geological Survey. Journals of the Legislative Assembly of the Province of Canada, 1844-5, v. 4, Appendix W, pp. 28-45.

LyeLL, C. 1830-1833. Principles of geology. 3 volumes (v.1, 1830; v.2, 1832; v.3, 1833). Murray, London.

Lyell, C. 1842, Notebook 103. In The letters, journals, and notebooks of Sir Charles Lyell, Lady Lyell, and other members of the family: The private collection of Lord Lyell of Kinnordy. 142 p.

LYELL, C. 1845. Travels in North America, in the years 1841-2; with geological observations on the United States, Canada, and Nova Scotia. Murray, London, v. 2, 272 p.

LyeLL, C. 1871. The student's elements of geology. Harper, New York, $640 \mathrm{p}$.

Lyell, C., \& Dawson, J.W. 1853. On the remains of a reptile (Dendrerpeton acadianum Wyman and Owen), and of a land shell discovered in the interior of an erect fossil tree in the coal measures of Nova Scotia. Quarterly Journal of the Geological Society of London, 9, pp. 58-63.

MAYNARD, J. R., \& LEEDER, M. R. 1992. On the periodicity and magnitude of Late Carboniferous glacio-eustatic sea-level changes. Journal of the Geological Society of London, 149, pp. 303-311.

New Brunswick Department of Natural Resources and ENERGY. 2000. Bedrock geology of New Brunswick. Minerals and Energy Division, Map NR-1, scale 1:500,000.

Plint, A.G. 1988. Sharp-based shoreface sequences and "offshore bars" in the Cardium Formation of Alberta: their relationship to relative changes in sea level. In Sea-level changes: an integrated approach. Edited by C.K. Wilgus, B.S. Hastings, C.A. Ross, H.W. Posamentier, J. Van Wagoner and C.G.St.C. Kendall. Tulsa, Oklahoma, Society of Economic Paleontologists and Mineralogists, Special Publication 42, pp. 357-370.

REIsz, R.R. 1997. The origin and early evolutionary history of amniotes. Trends in Ecology and Evolution, 12, pp. 218-222.

Robinson, J.M. 1991. Phanerozoic atmospheric reconstructions - a terrestrial perspective. Palaeogeography, Palaeoclimatology, Palaeoecology, 97, pp. 51-62.

Rust, B.R., Gibling, M.R., \& Legun, A.S. 1984. Coal depositional in an anastomosing-fluvial system: the Pennsylvanian Cumberland Group south of Joggins, Nova Scotia, Canada. In Sedimentology of coal and coal-bearing sequences. Edited by R.A. Rahmani and R.A. Flores. International Association of Sedimentologists Special Publication 7, pp. 105-120.

Ryan, R.J., \& Boehner, R.C. 1994. Geology of the Cumberland Basin, Cumberland, Colchester and Pictou Counties, Nova Scotia. Halifax, Nova Scotia Department of Natural Resources, Memoir 10, 222 p.

Ryan, R.J., Boehner, R.C., Deal, A., \& CAlder, J.H. 1990. Cumberland Basin geology map, Amherst, Springhill and Parrsboro, Cumberland County. Nova Scotia Department of Mines and Energy, Map 90-12, scale 1:50 000.

Ryan, R.J., Boehner, R.C., \& CAlder, J.H. 1991. Lithostratigraphic revisions of the upper Carboniferous to lower Perm- ian strata in the Cumberland Basin, Nova Scotia and the regional implications for the Maritimes Basin in Atlantic Canada. Bulletin of Canadian Petroleum Geology, 39, pp. 289-314.

RygEL, M.C. 2005. Alluvial sedimentology and basin analysis of Carboniferous strata near Joggins, Nova Scotia, Atlantic Canada. Unpublished Ph.D. thesis, Dalhousie University, Halifax, Nova Scotia, $468 \mathrm{p}$.

Rygel, M.C., \& SHipley, B.C. 2005. "Such a section as never was put together before": Logan, Dawson, Lyell, and mid-Nineteenth-Century measurements of the Pennsylvanian Joggins section of Nova Scotia. Atlantic Geology, 41, pp. 87-102.

Rygel, M.C., Gibling, M.R., \& Davies, S.J. 2001. Alluvial architecture of the Joggins Formation, Atlantic Canada - the evolution of fluvial style in a rapidly subsiding Carboniferous floodplain. $7^{\text {th }}$ International Conference on Fluvial Sedimentology, Program and Abstracts, p. 238.

Rygel, M.C., Gibling, M.R., \& Calder, J.H. 2004. Vegetation-induced sedimentary structures from fossil forests in the Pennsylvanian Joggins Formation, Nova Scotia. Sedimentology, 51, pp. 531-552.

ScotT, A.C. 1998. The legacy of Charles Lyell: advances in our knowledge of coal and coal-bearing strata. In Lyell, the past is the key to the present. Edited by D.J. Blundell and A.C. Scott. Geological Society of London, Special Publication 143, pp. 243-260.

Scotт, A.C. 2001. Roasted alive in the Carboniferous. Geoscientist, 11, pp. 4-7.

SHAw, W.S. 1951a. The Cumberland Basin of deposition. Unpublished Ph.D. thesis, Massachussets Institute of Technology, Cambridge, Massachusetts, $170 \mathrm{p}$.

SHAw, W.S. 1951b. Preliminary map, Springhill, Cumberland, and Colchester counties, Nova Scotia. Geological Survey of Canada, Paper 51-11.

Skilliter, D.M. 2001. Distal marine influence in the Forty Brine section, Joggins, Nova Scotia, Canada. Unpublished M.Sc. thesis, Boston College, Boston, Massachusetts, 96 p.

Smith, M.G. 1991. The floodplain deposits and palaeosol profiles of the Late Carboniferous Cumberland Coal Basin, exposed at Joggins, Nova Scotia, Canada. Unpublished M.Sc. thesis, University of Guelph, Guelph, Ontario, 372 p.

Solem, A., \& Yochelson, E.L. 1979. North American Paleozoic land snails, with a summary of other Paleozoic nonmarine snails. United States Geological Survey, Professional Paper 1072, $42 \mathrm{p}$.

Soreghan, G.S., \& Giles, K.A. 1999. Amplitudes of Late Pennsylvanian glacioeustasy. Geology, 27, pp. 255-258.

St. Peter, C. 2001. Carboniferous geological compilation map of southeastern New Brunswick comprising NTS quadrangles $21 \mathrm{H} / 10,21 \mathrm{H} / 15,21 \mathrm{H} / 16,21 \mathrm{I} / 01,21 \mathrm{I} / 02$, and $11 \mathrm{~L} / 04$, New Brunswick Department of Natural Resources and Energy, Minerals and Energy Division, Plate 2001-5, scale 1:150 000.

Tenière, P.J. 1998. Sedimentology, facies successions and 
cyclicity of a section of the Joggins Formation, Nova Scotia. Unpublished B.Sc. thesis, Dalhousie University, Halifax, Nova Scotia 84 p.

Tibert, N.E., \& DeWEy, C.P. 2005. Taxonomic significance of the ostracode species Carbonita altilis (Jones and Kirkby 1879) from the Pennsylvanian Joggins Formation, Atlantic Canada. Geological Association of Canada Annual Meeting, Halifax, Nova Scotia, v. 30.

Tye, R.S., \& Coleman, J.M. 1989. Depositional processes and stratigraphy of fluvially dominated lacustrine deltas: Mississippi Delta plain. Journal of Sedimentary Petrology, 59, pp. 973-996.

UtTing, J., \& WAgner, R.H. 2005. Megaflora of the Upper Carboniferous Cumberland Group, Joggins area, Nova Sco- tia and New Brunswick. Geological Association of Canada Annual Meeting, Halifax, Nova Scotia, Abstracts Volume 30, p. 197.

Waldron, J.W.F., \& Rygel, M.C. 2005. Role of evaporite withdrawal in the preservation of a unique coal-bearing succession: Pennsylvanian Joggins Formation, Nova Scotia. Geology, 33, pp. 337-340.

Wilberforce, S. 1860. On the origin of species. Quarterly Review, 1860, pp. 225-264.

Editorial responsibility: Robert A. Fensome

\section{APPENDIX A}

Measured section of the Joggins Formation from Lower Cove to south of Bell's Brook.

\section{EXPLANATION OF SEDIMENTOLOGICAL LOG}

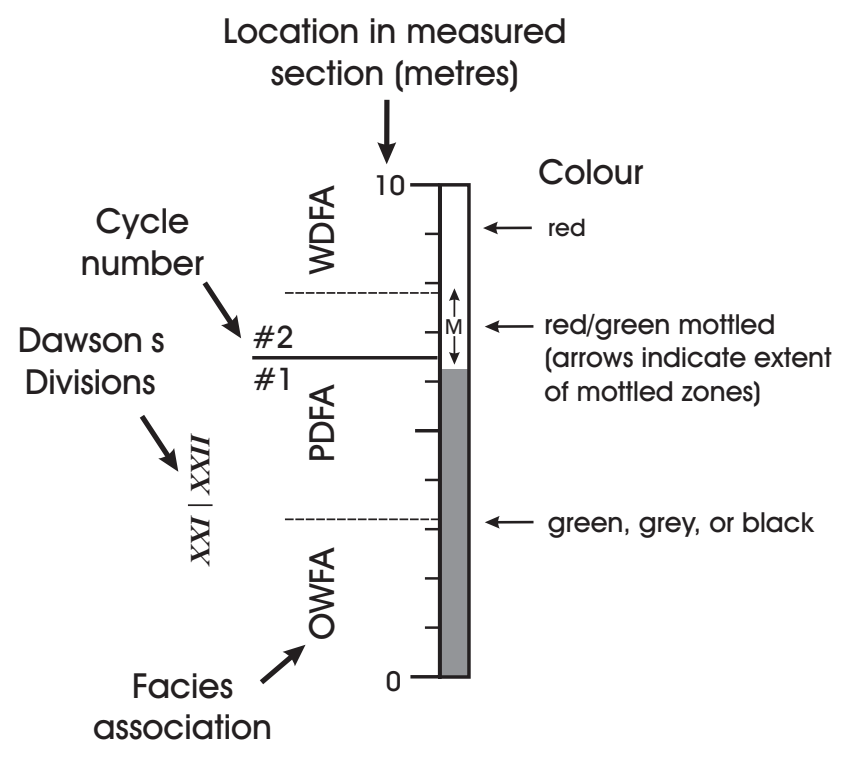

TIDAL FLAT OUTCROPS

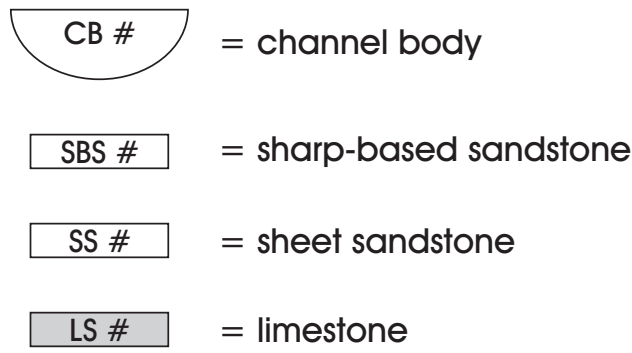

\# indicates meterage at top of the bed (to the nearest metre)

\section{FACIES ASSOCIATIONS}

OWFA = open-water facies association

PDFA $=$ poorly drained facies association

WDFA $=$ well drained facies association
ORGANIC HORIZONS

ए LS = limestone

$-\leftarrow$ Coal (Logan \# if applicable)

$\leftarrow$ CS $=$ carbonaceous shale

$\longleftarrow \mathrm{OR}=$ organic-rich horizon 


\section{SYMBOLS USED IN SEDIMENTOLOGICAL LOG}

- concretion or nodule (calcareous)

- concretion or nodule (non-calcareous)

$\$ 00$ calcareous rip-up clast

800 mud-chip rip-up clast

climbing ripple cross-lamination

\section{SEDIMENTARY FEATURES}

u wave ripple

m ripple cross-lamination

$\smile$ trough cross-bedding

$\mathscr{W}$ planar cross-bedding

\section{FLORA}

Stigmaria $\mathrm{Sp}$.

cordaite gymnosperm (in situ)

1 Artisia transversa (cordaite pith cast)

Cordaites principalis (cordaite leaf)
$=$ horizontal lamination

$\smile$ groove cast or tool mark

$\times \quad$ pedogenic slickenside

145 convolute bedding

\section{FAUNA}

$\because \quad$ Diplichnites (Arthropleura trackway)

Q bivalve

(c) ostracode
๑) Spirorbis

8 Dendropupa vetusta

$\Longleftarrow$ tetrapod bone (t) finely macerated plant material

$\wedge$ root compression

$\because$ charcoal

ply tetrapod trackway

(1) fish bone or scale 

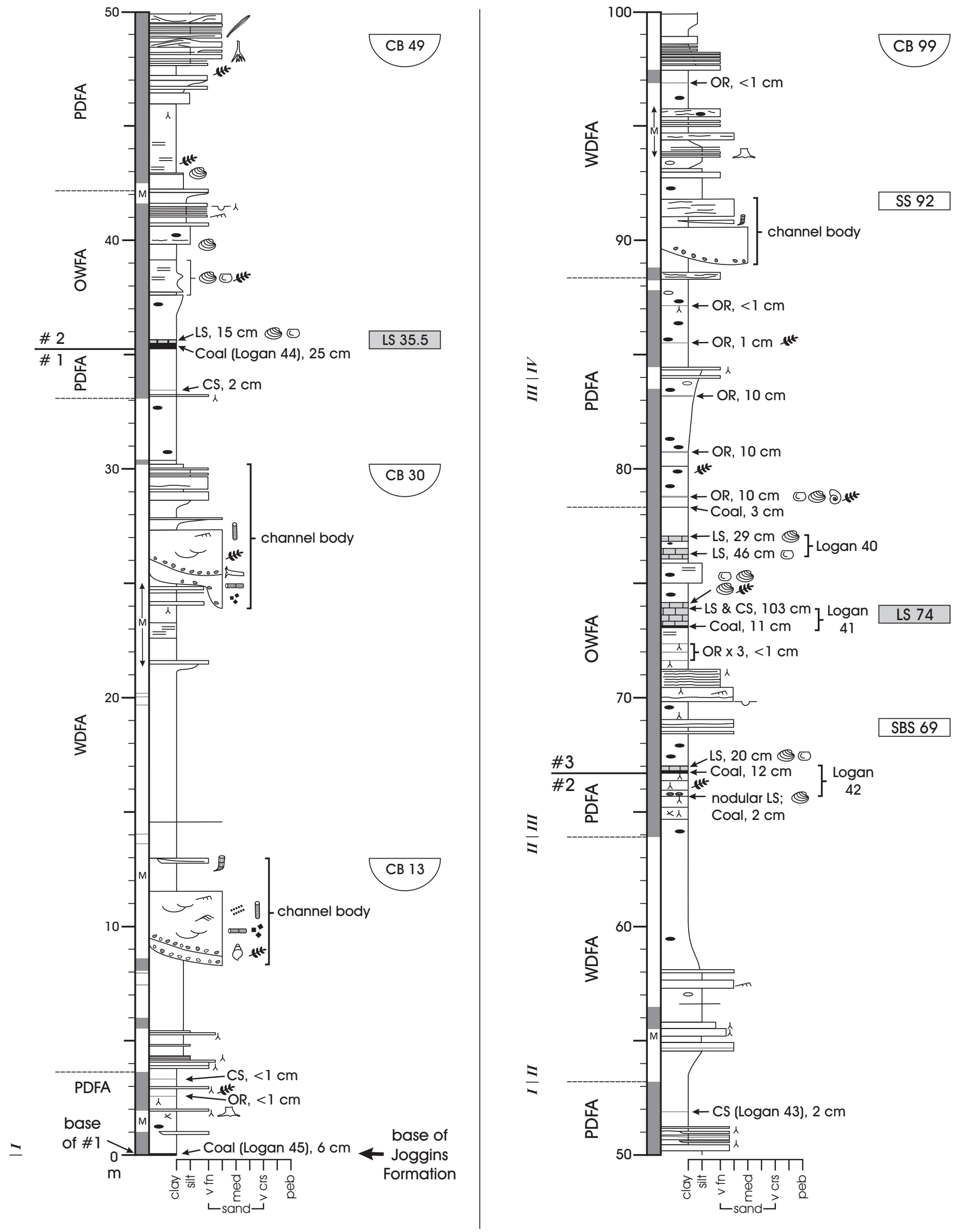

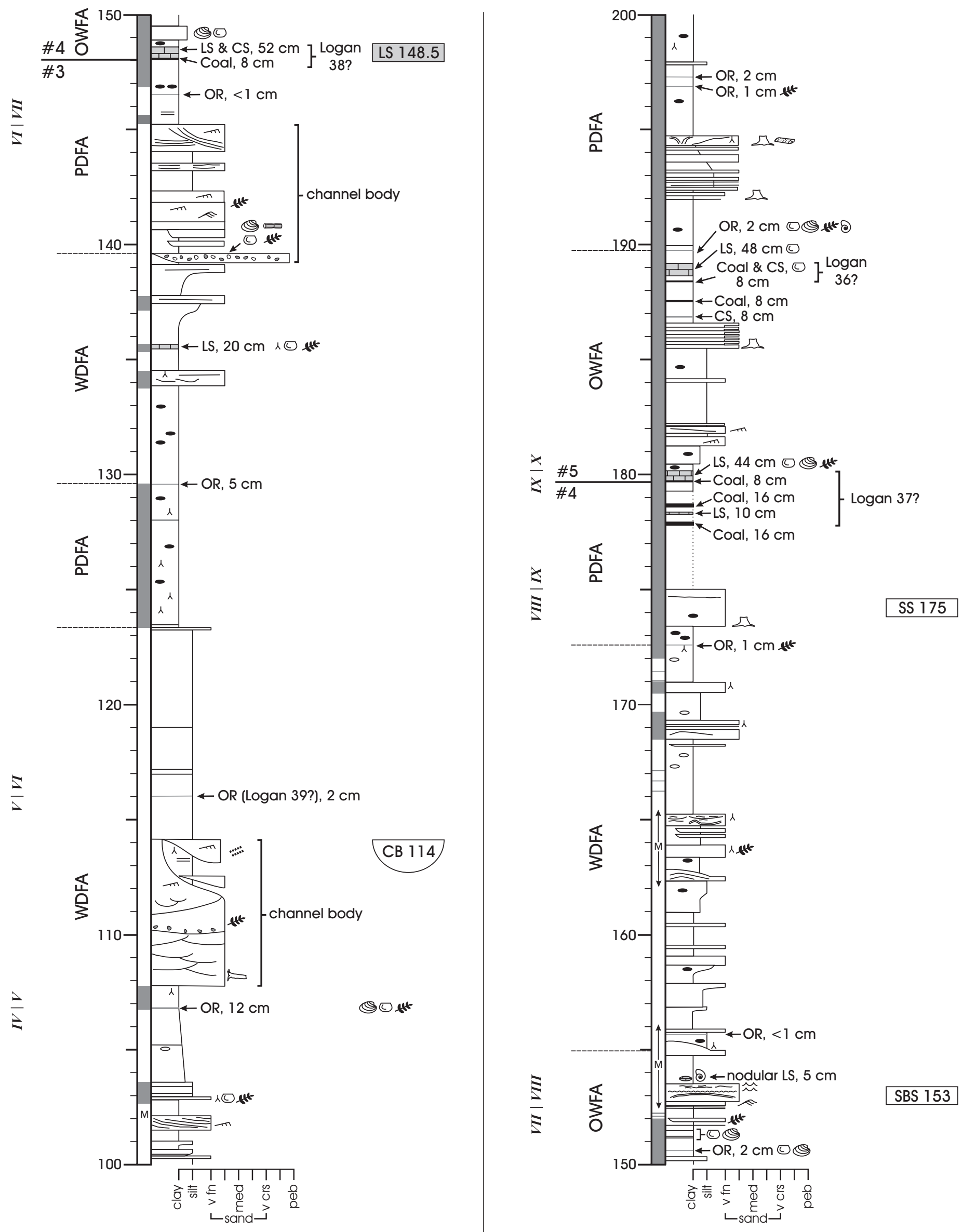

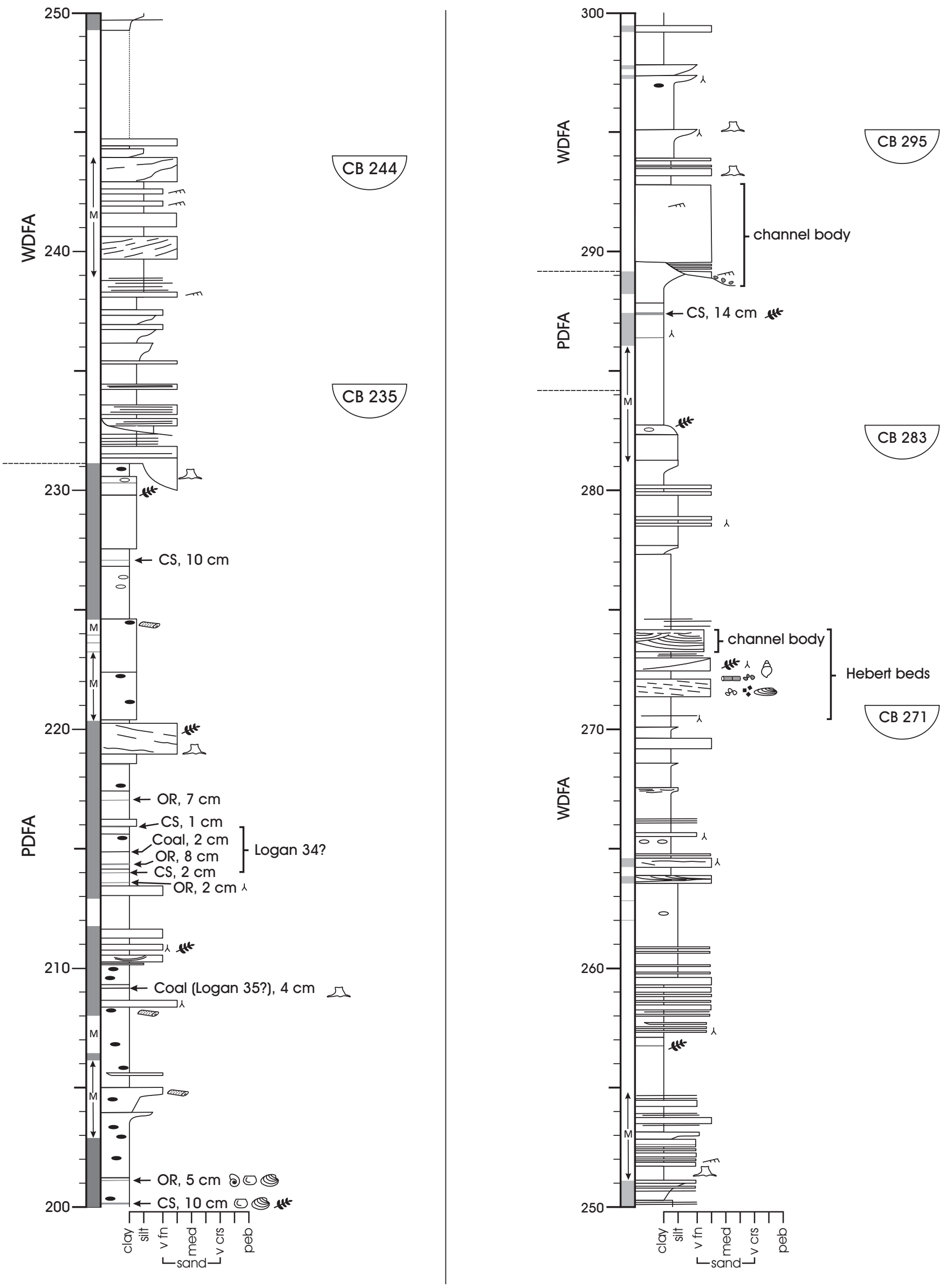

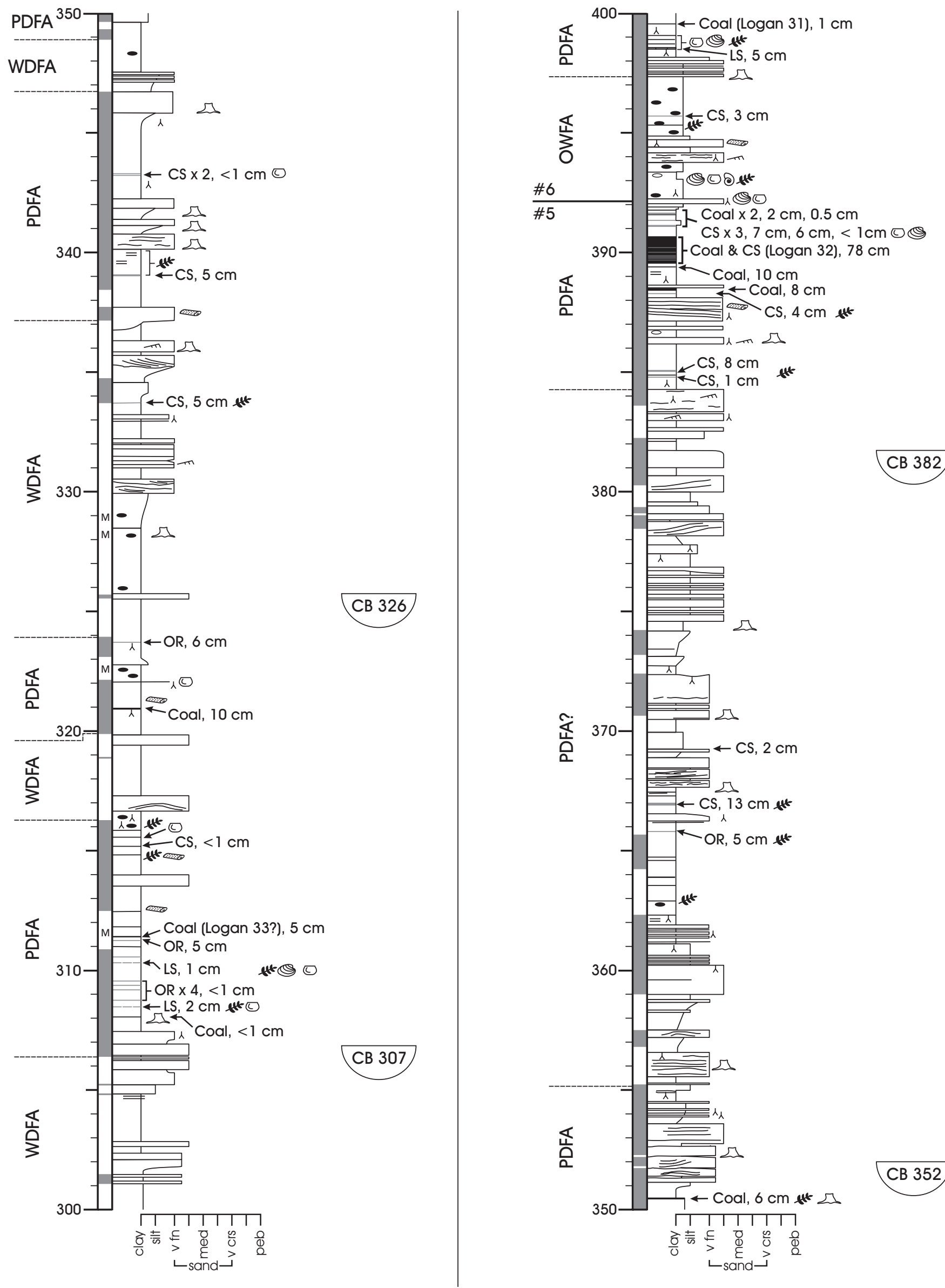

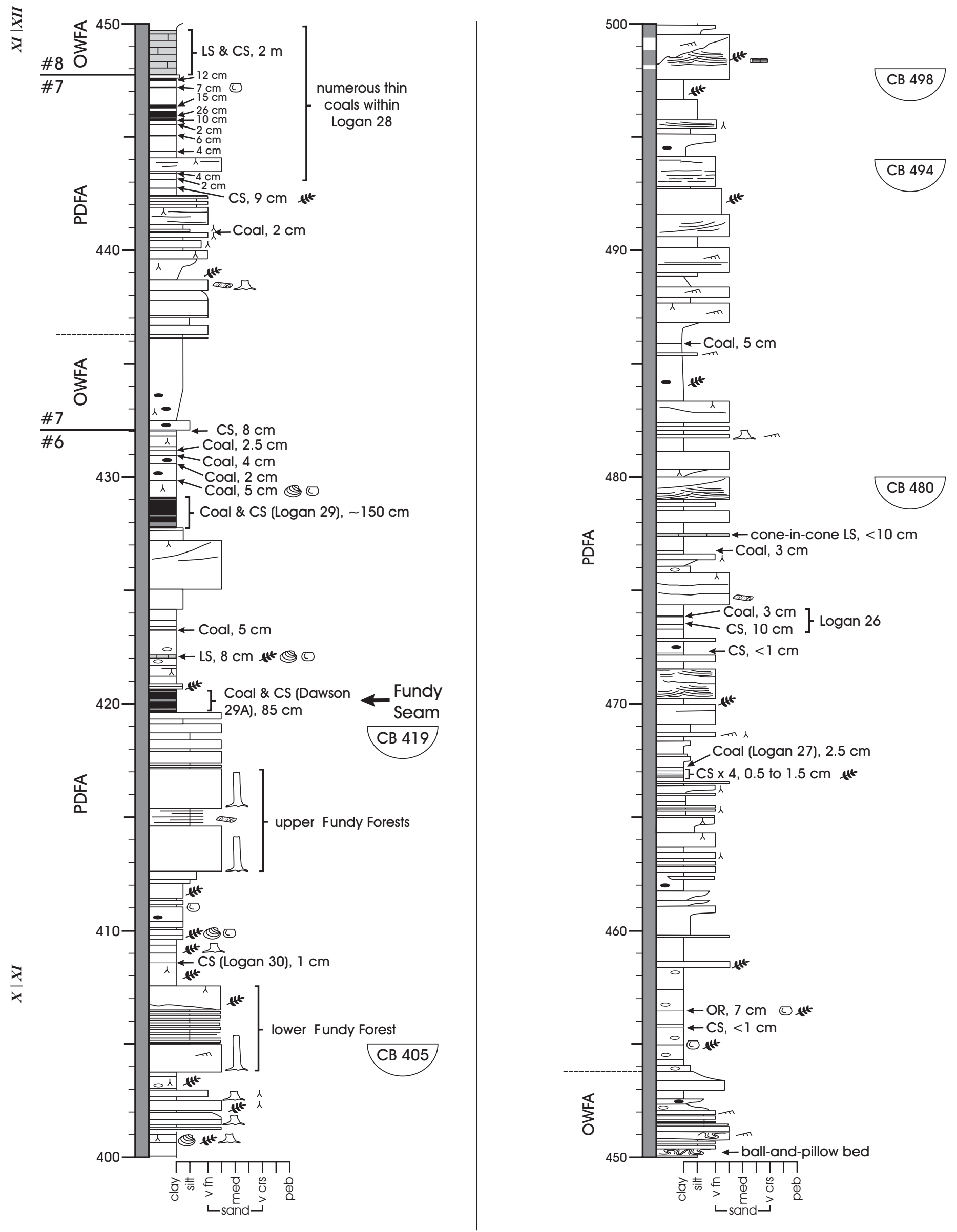

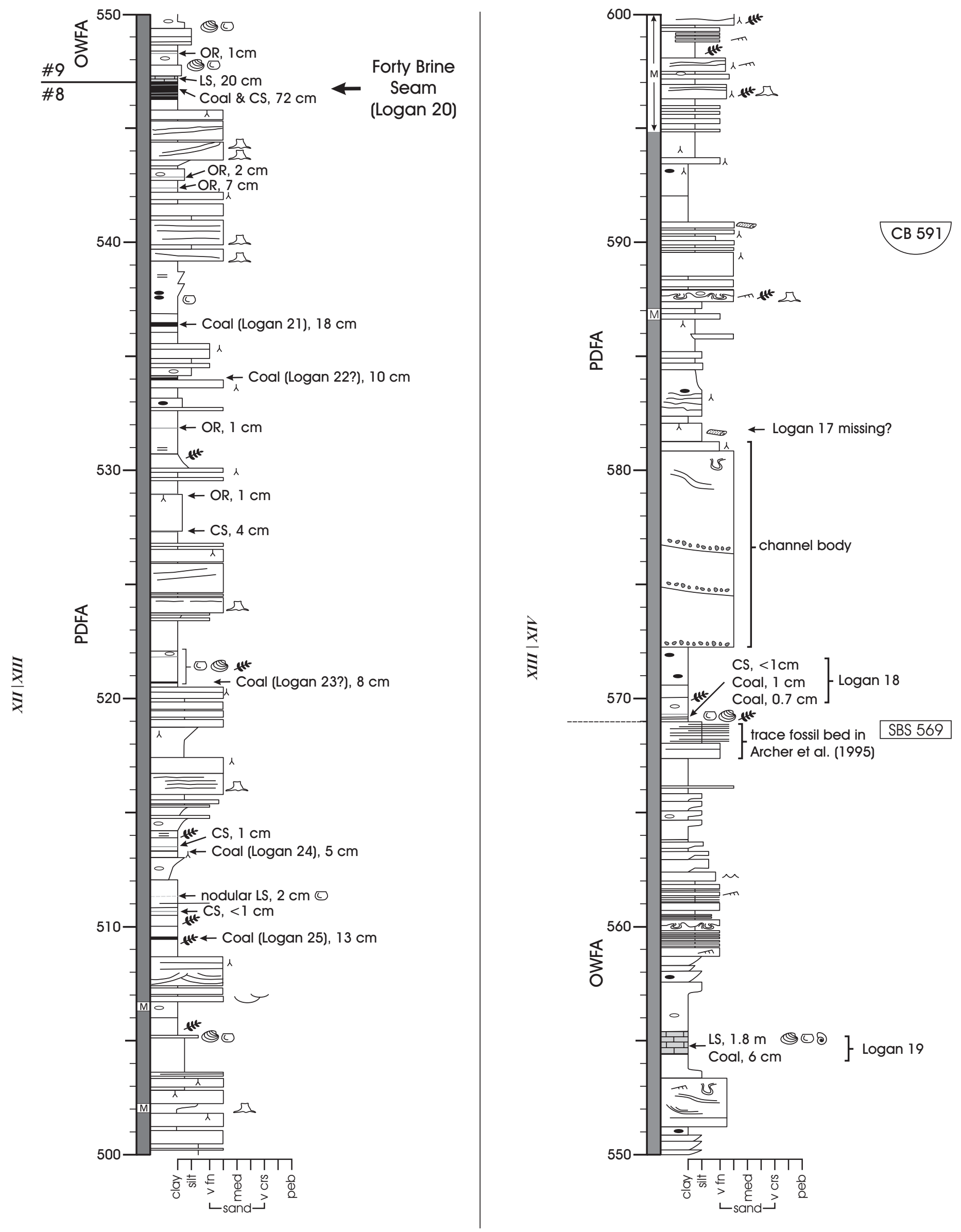

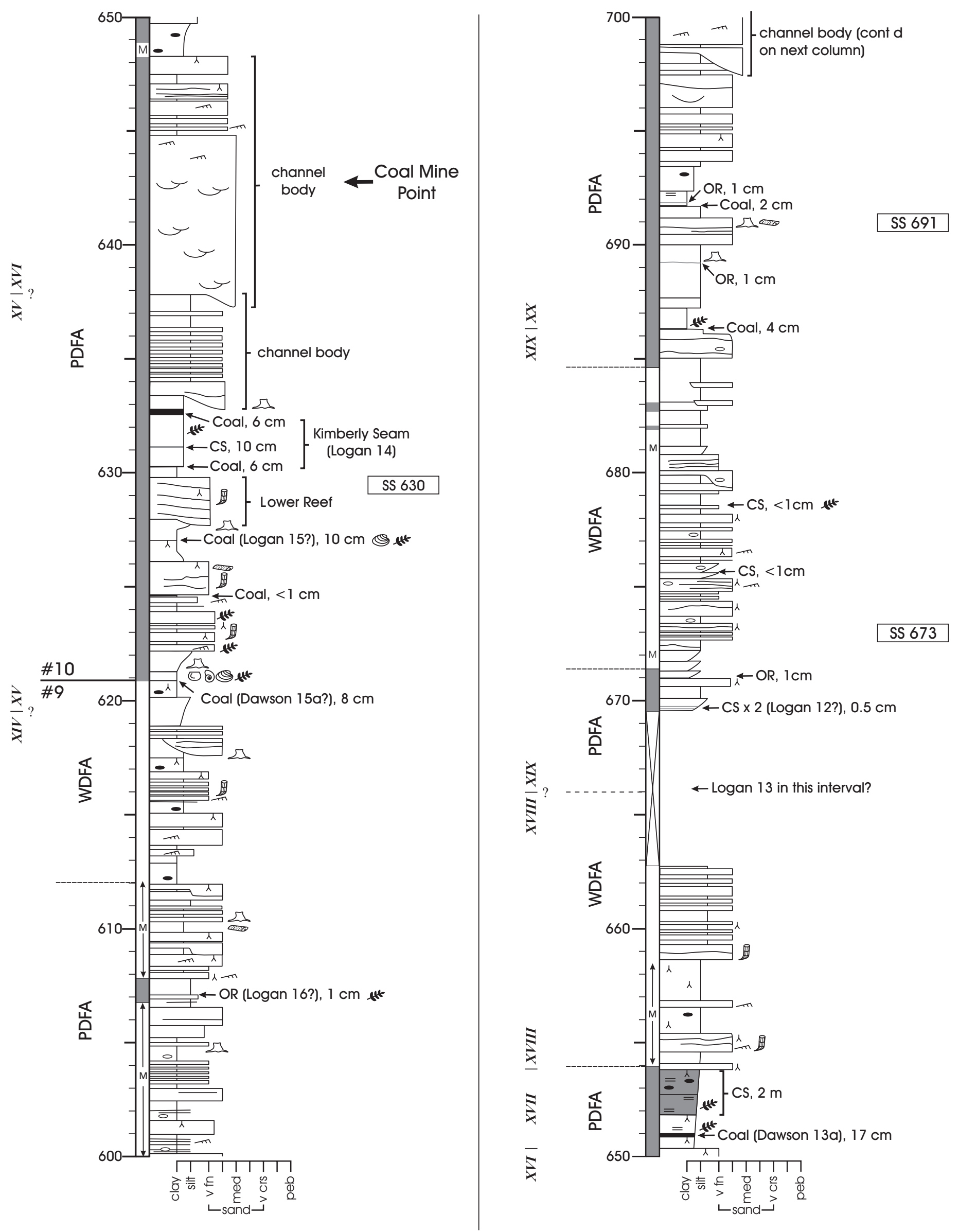

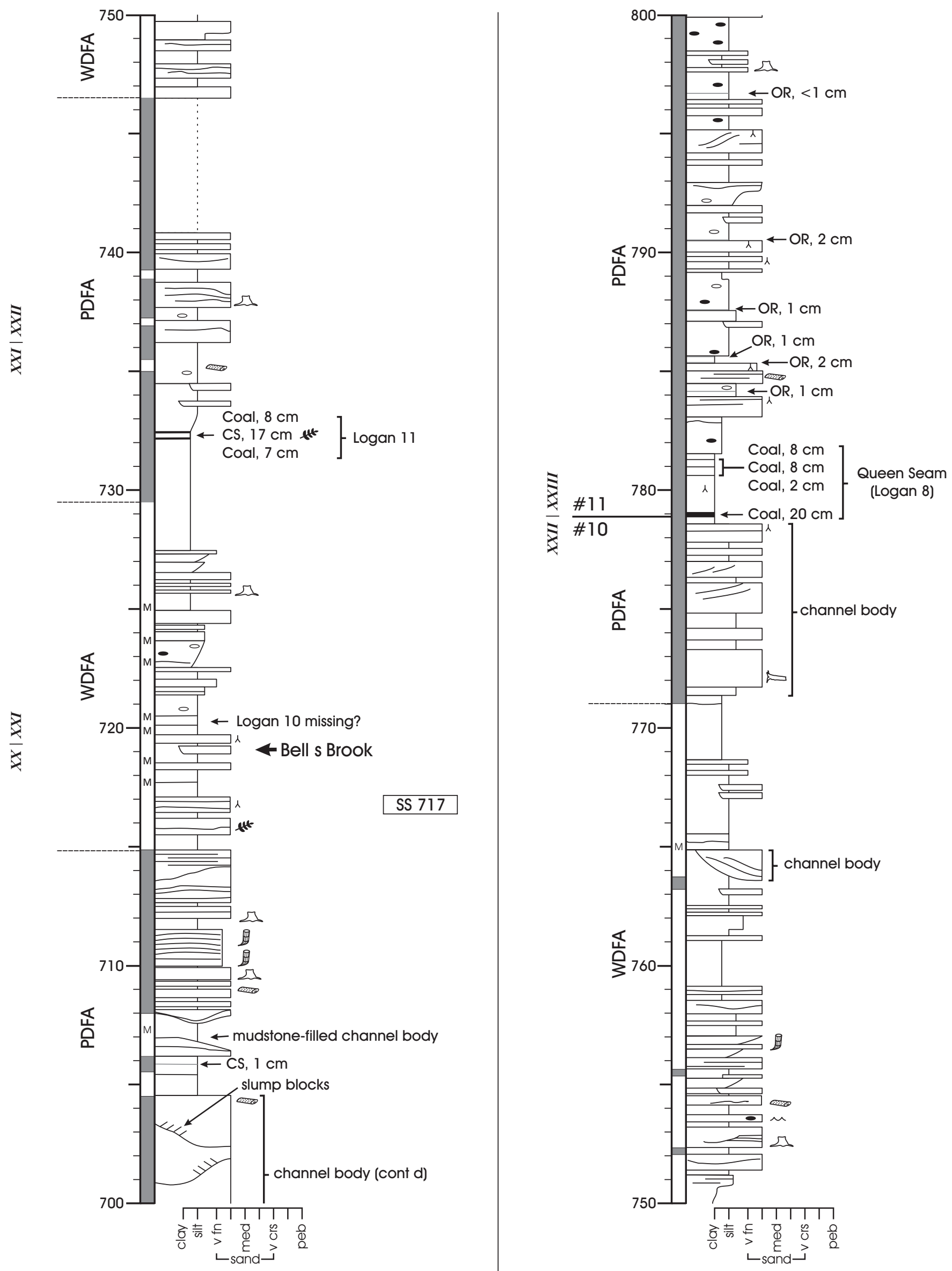

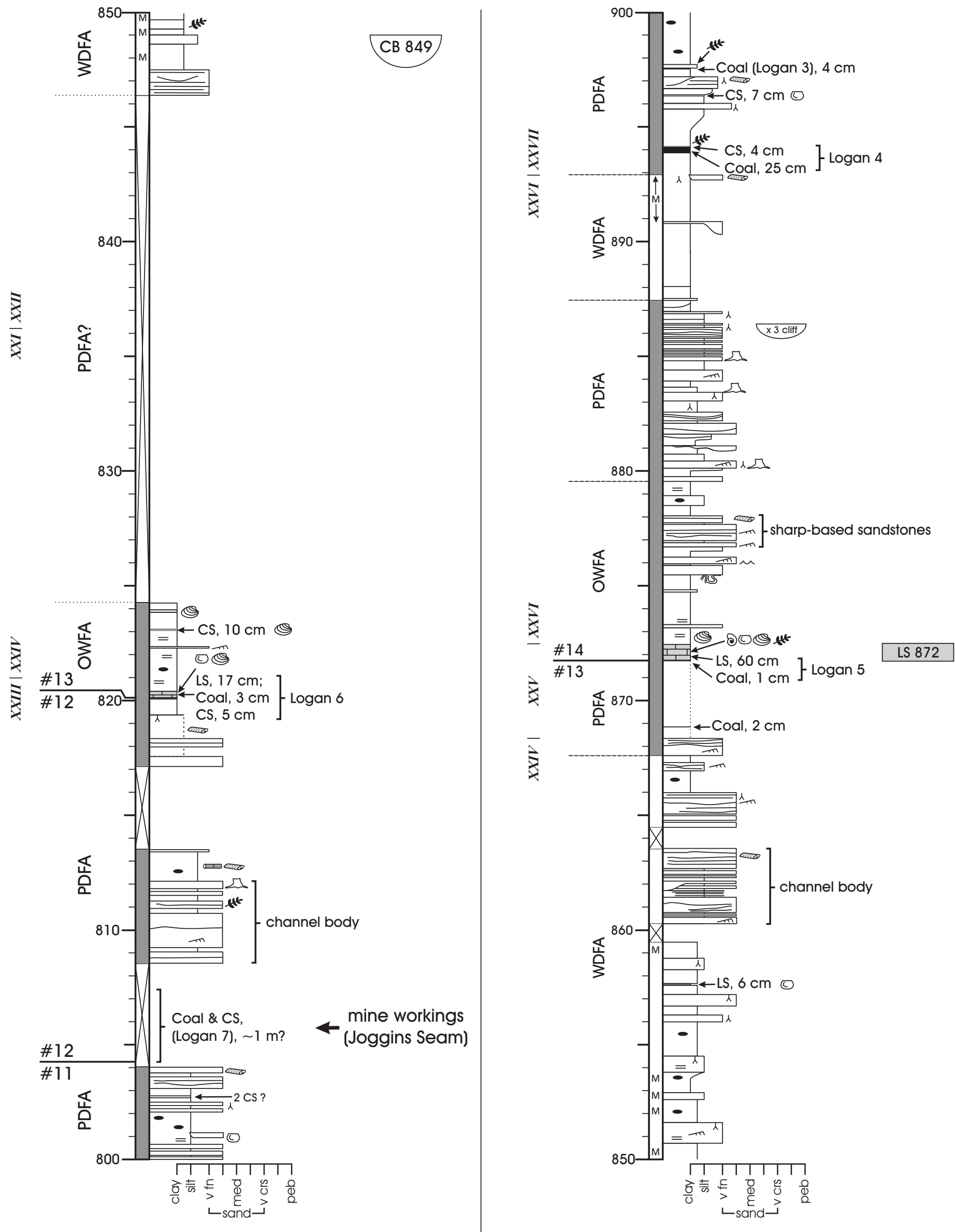


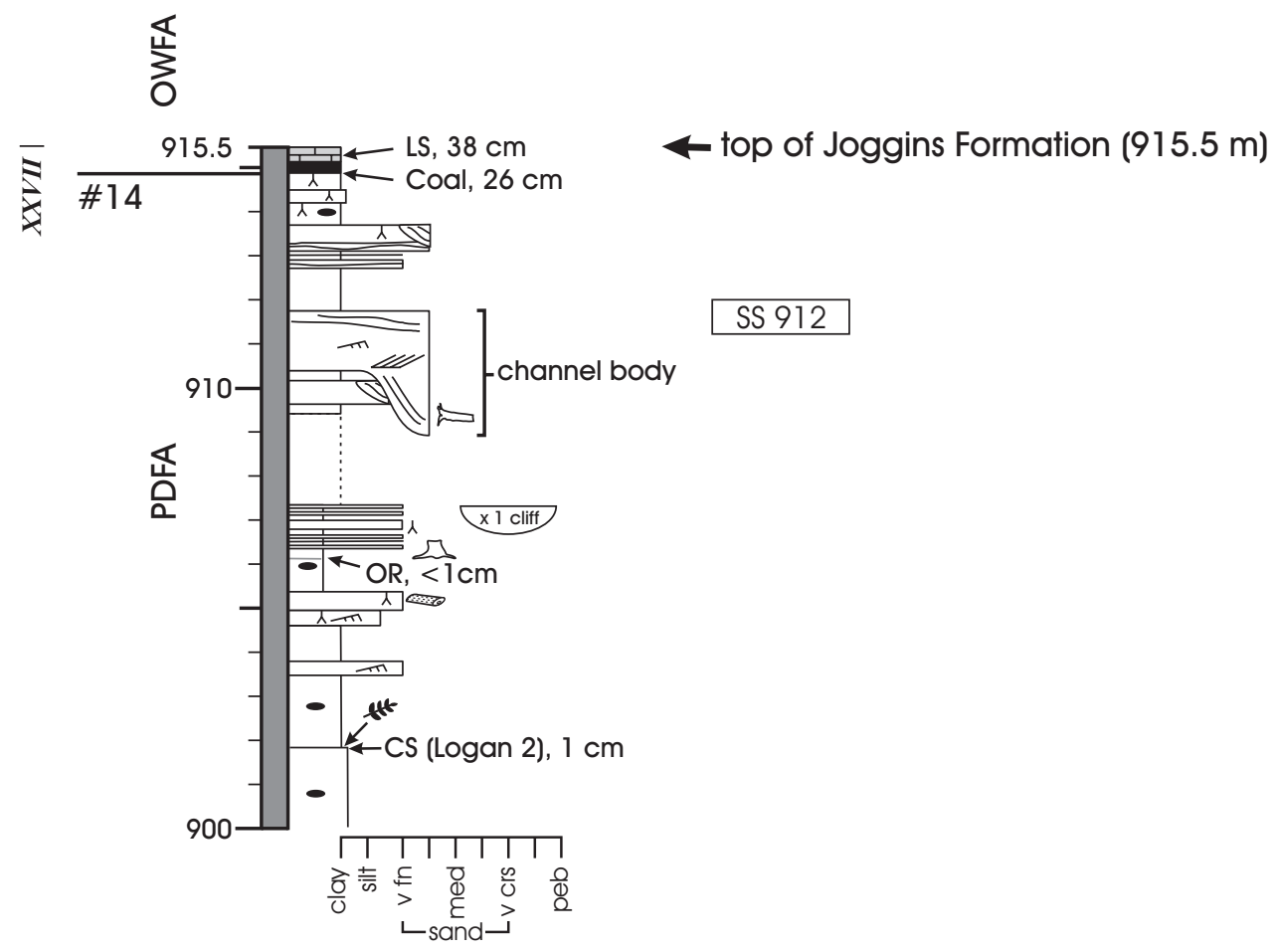

